\title{
Rakouské parlamentní volby 2017: Začátek éry Sebastiana Kurze
}

\author{
The 2017 Austrian Parliamentary Elections: The Beginning of the \\ Sebastian Kurz Era
}

MirosLAV ŠEPTÁK ${ }^{1}$

\begin{abstract}
The article deals with the early parliamentary elections in Austria, which resulted from conflicts inside the government. The situation provides a negative example of a long rule of grand coalition. Most Austrians had lost the trust in abilities of the cabinet made up by social democrats (SPÖ) and Austrian People's Party (ÖVP) to deal with problems of the day. The public demanded an end to controversies and change of political style. In the stalemate situation it was ÖVP which initiated irregular elections into National Council. It succeeded in connecting the dynamic and perspective personality of the leader Sebastian Kurz with the image of a new and open movement. During the campaign, it emphasized themes which the Austrian public considered important (migration and asylum policy, better security, reduction of taxes) in combination with professional political marketing. After the elections, negotiations revealed programmatic overlap between ÖVP and Freedom Party of Austria, which placed third, in a number of important areas. The new government worked out an ambitious reform program, for which it secured enough majority support in the National Council; also the favourable economic conditions helped. The article provides analysis of electoral programs and the respective stages of the electoral campaign, making use of extensive electoral materials, including unarchived ones. Besides filling a major descriptive-analytic gap in the Czech scholarly reflection of Austrian politics, the article probes into actual trends of Austrian electoral marketing and electoral behaviour.
\end{abstract}

Keywords: Austria; Parliamentary Elections; National Council; ÖVP; SPÖ; FPÖ

\footnotetext{
1 Odborný asistent, Ústav česko-německých areálových studií, Filozofická fakulta, Jihočeská univerzita, Branišovská 31a, 37005 České Budějovice / Assistant Professor, Institute of Czech-German Area Studies and Germanistics, Faculty of Arts, University of South Bohemia, České Budějovice, Czech Republic. E-mail: mseptak@ff.jcu.cz. Archivář, Národní archiv, Oddělení fondů nestátní provenience a archivních sbírek, Archivní 2257/4, 14900 Praha / Archivist, Departement of Non-state Provenance Archival Fond and Collections, Praha, Czech Republic. Email: miroslav.septak@nacr.cz. Autor chce poděkovat Markétě Maturové a oběma anonymním recenzentům za kritické poznámky $\mathrm{k}$ textu.
} 


\section{1. Úvod}

$\mathrm{Na}$ podzim 2017 proběhly ve střední Evropě v rychlém sledu za sebou parlamentní volby v Německu, Rakousku a České republice. Především souboj o hlasy voličů do rakouské Národní rady přinesl několik zásadních a zajímavých momentů $\mathrm{v}$ podobě jedinečného současného posílení Rakouské lidové strany (Österreichische Volkspartei, ÖVP) a Svobodné strany Rakouska (Freiheitliche Partei Österreichs, FPÖ), porážky úřadujícího kancléře, pozbytí parlamentní relevance Zelených (Die Grünen - Die Grüne Alternative) po 31 letech a ojedinělého zvýšení koaličního potenciálu Svobodných v rámci povolebních vyjednávání.

Analýza rakouských voleb na spolkové nebo zemské úrovni patři mezi poměrně časté náměty především rakouské politické vědy. Tyto odborné studie vycházející z průzkumů veřejného mínění realizovaných $\mathrm{v}$ krátkodobé časové perspektivě (maximálně dvou měsíců) si kladou za cíl odůvodnit motivy, které vedly $\mathrm{k}$ podpoře jednotlivých kandidujících stran, a tedy $\mathrm{k}$ samotným volebním výsledkům. ${ }^{2}$ Od parlamentních voleb 2013 pokračující postupné oslabování voličské prrízně vládních lidovců a sociálních demokratů (Sozialdemokratische Partei Österreichs, SPÖ) odůvodňují nevýraznou prací rakouského kabinetu a růstem významu azylové a migrační otázky u rakouského elektorátu. Důležitým aspektům volební analýzy, které lépe vystihují dynamiku současné rakouské politické scény, tedy volebním programům a volební kampani, přitom věnují minimální nebo žádnou pozornost.

Uvedené tvrzení platí rovněž o české politické vědě. Naposledy o volbách do Národní rady v kontextu analýzy volebních programů a průběhu volební kampaně pojednal brněnský politolog Vít Hloušek (2008: 208-210). Ojedinělá pozdější studie (Hnát 2013) redukuje svá odborná zamyšlení na analýzu teritoriálních rozdílů $v$ podpoře jednotlivých stran, vycházejíc prritom z relevantních statistických dat zveřejněných rakouským Spolkovým ministerstvem vnitra.

Pro rakouské parlamentní volby 2017 mají zásadní význam dvě monografie. První, sborník editovaný rakouskou publicistkou Barbarou Tóthovou a politologem Thomasem Hoferem, navazuje na tradici z minulých let. Představuje kombinaci př́spěvků osob spjatých $\mathrm{v}$ rozmanitých funkcích prímo s relevantními rakouskými politickými stranami s analýzami odborníků z oblasti společenských věd, jež byly vypracovány s odstupem několika týdnů po proběhnutí voleb do Národní rady (Hofer a Tóth 2017). ${ }^{3}$ Př́nos takto koncipované monografie spočívá v poskytnutí dobového svědectví osob, které měly možnost sledovat průběh volební kampaně „zevnitř jednotlivých politických stran. Současně však bude nutné tato tvrzení konfrontovat s pozdějším vývojem. Snaha být co nejaktuálnější totiž vedla

\footnotetext{
2 Tyto studie vycházejí především v pravidelné ročence Österreichisches Jahrbuch für Politik.

3 Takto koncipovaná kolektivní monografie je vydávána v souvislosti s každými rakouskými parlamentními volbami od roku 2006 (Hofer a Tóth 2007).
} 
k opomenutí nezbytného finále parlamentních voleb - povolebních jednání a utvoření vládní koalice.

Druhá monografie od rakouských politologů Fritze Plassera a Franze Sommera přibližuje rakouské parlamentní volby na základě velkého množství sociologických šetření v dlouhodobé časové perspektivě, pomocí nichž přináší pronikavou analýzu zásadních změn programatických preferencí rakouského elektorátu v souvislosti s mezinárodní uprchlickou krizí (Plasser a Sommer 2018).

Obě zmíněné knihy hledají odpověd’ na otázku, proč lídr SPÖ a úřadující rakouský ministerský předseda Christian Kern nedokázal využít strategickou výhodu $\mathrm{v}$ podobě tzv. kancléŕského bonusu a podlehl hlavnímu vyzyvateli představiteli menší koaliční strany, lidovci Sebastianu Kurzovi. Př́čciny spatřují v lepši adaptaci ÖVP na změnu tematických priorit rakouských voličů a jejich prání změnit politický styl plný vzájemných koaličních rozporů a hádek.

$\mathrm{Na}$ rozdíl od obou zmíněných prací věnuji pozornost analýze volebních programů a jednotlivým fázím volebním kampaně, jež představují konkrétní pŕiklad aplikace volebního marketingu a v konečném důsledku podstatně ovlivnily výsledky voleb do Národní rady. Volební materiály zohledňuji v celé jejich šíri, tj. neopomíjím například účelové výtahy z volebních programů, letáky a další neperiodické tiskoviny (v rakouském prostředí zpravidla nikde nearchivované materiály) vzniknuvší jako bezprostřední reakce na aktuální volební témata, nebo mediální výstupy lídrů jednotlivých politických stran. ${ }^{4}$ Jejich využití umožňuje lépe přibližit zvolenou strategii s cílem oslovení co nejširšího spektra elektorátu. Současně dává konkrétní odpověd’ na otázku, proč došlo v posledních dvou týdnech volební kampaně $\mathrm{k}$ podstatné změně voličských preferencí především u príznivců sociální demokracie a Zelených.

Studie si klade za cíl postihnout klíčové aspekty, které směrodatným způsobem přispěly $\mathrm{k}$ výsledkům mimořádných voleb do Národní rady. Pozornost věnuji také na rakouské poměry dosud jedinečnému současnému posílení lidovců a Svobodných a ojedinělému zvýšení koaličního potenciálu FPÖ během povolebních vyjednávání, tedy aspektům, které dosavadní odborná literatura podceňuje. Vedle v českém odborném prostředí dosud zcela absentující informační báze by měl článek prínést sondáž do aktuálních trendů rakouského volebního marketingu a voličského chování. Ve druhé sekci se zaměřím na př́činy rozpadu velké koalice sociálních demokratů a lidovců a „startovací“ pozici jednotlivých stran do volební kampaně. Ve třetí analyzuji intenzivní volební kampaň s důrazem na programové priority a jedinečnosti jednotlivých politických stran. ${ }^{5} \mathrm{~V}$ poslední sekci se budu věnovat okolnostem vytváření nové koaliční vlády.

\footnotetext{
${ }^{4}$ Politické strany a hnutí mají podle platné rakouské legislativy povinnost uchovávat dokumenty a umožnit výběr archiválií (dokumentů trvalé hodnoty), v drtivé většině však - stejně jako v České republice - uvedení soukromoprávní původci tuto skutečnost ignorují.

${ }^{5}$ Srov. definici italského politologa Giovanni Sartoriho (Sartori 2005: 126-128).
} 


\section{Rozpad vládní koalice}

Př́činy loňských parlamentních voleb je nezbytné hledat v událostech proběhnuvších o čtyři roky dříve. Ve volbách do Národní rady v září 2013 dosáhla SPÖ a ÖVP nejhorš́ího výsledku (Jenny a Müller 2014; BMI 2013). Obě strany se rozhodly prodloužit vládní kooperaci, trvající na spolkové úrovni nepřetržitě od roku 2006, formou velké koalice (Kritzinger, Müller a Schönbach 2014: 235-236). Nechyběly přitom četné hlasy z řad opozice a některých médií, zda by nebylo vhodnější místo dosavadního modelu spolupráce vyzkoušet na spolkové úrovni dosud neaplikovaný trojkoaliční formát (Khol 2014). Pochybnosti vyvolávala rovněž skutečnost, zda minimální personální obměna povede ke zvýšení akceschopnosti vlády ve srovnání s předchozím obdobím. ${ }^{6}$

Ačkoli členové kabinetu pod vedením sociálního demokrata Wernera Faymanna spolu se směrodatnými představiteli obou koaličních partnerů proklamovali ukončení vzájemných rozmíšek a blokády s cílem (znovu)získat důvěru obyvatel v konstruktivní politiku (Kurz 2014: 196; Schieder 2014: 212-214; Lopatka 2014; Brandstätter 2014; Neisser 2014), opak byl pravdou. Zásadní reformy, predevším v oblasti vzdělání, penzijního a sociálního systému, zůstaly z velké části jen na papíre. Realizované daňové změny nedokázala vláda odpovídajícím zpơsobem vysvětlit veřejnosti.

V roce 2015 ovlivnila podstatným způsobem (nejenom) rakouskou vnitropolitickou scénu mezinárodní uprchlická krize. Navzdory velkému nasazení jednotlivců, dobrovolných organizací a státních orgánů způsobily desítky tisíc uprchlíků značné logistické problémy. Události nabraly vlastní dynamiku (Ultsch, Prior a Nowak 2017). Veřejnost si začala klást otázky, kolik uprchlíků Rakousko ještě může přijmout, jak proběhne integrace velkého množství lidí z jiného kulturního prostředí do většinové rakouské společnosti a zda takovýto vývoj neprrispěje k sociálním konfliktům a v konečném důsledku ke zvýšení kriminality.

Kombinace vnitrokoaličních konfliktů, vzájemné blokády, chybějící odvahy provést rozsáhlejší reformy, zvýšené nezaměstnanosti a klesající výkonnosti rakouské ekonomiky, spolu s nesouladem mezi lidovci a socialisty v azylové otázce, vedly k rostoucí nespokojenosti obyvatel Rakouska. V lednu 2016 dvě třetiny z nich hodnotily výkony velké koalice negativně. Každý druhý volič vyjadřoval pochybnosti o akceschopnosti vlády, každý čtvrtý ji dokonce považoval za vnitřními spory ochromenou jednat v důležitých otázkách rakouské politiky (Plasser a Sommer 2018: 35-36). ${ }^{7}$ Odstoupení Wernera Faymanna v květnu 2016 z čela spolkového kancléřství i z vedení sociální demokracie a jeho nahrazení Christianem Kernem znamenalo pouze dočasné vylepšení vnímání práce vlády (Pink 2017). Voliči měli stále častěji pocit, že se

6 Pronikavou analýzou bilance vlády Wernera Faymanna v letech 2008 až 2013 představuje Prapotnik (2014).

${ }^{7}$ K podobným číslům dochází také sociolog a politolog Peter Hajek (2017: 177). 
koalice zabývá spíše svými vlastními interními rozmíšami, než aby řešila každodenní problémy obyvatel Rakouska.

Pokles prrízně elektorátu sociálních demokratů a lidovců kontrastoval se vzestupem opoziční Svobodné strany Rakouska. FPÖ těžila nejenom z matné vládní bilance, ale především ze zásadní změny klíčových témat rakouské vnitřní politiky způsobené mezinárodní uprchlickou krizí. Zatímco v roce 2013 dominovala problematika potírání korupce a rostoucí náklady na bydlení, o čtyrí roky později veřejnost pokládala za zásadní společenská témata azylovou a migrační otázku spolu s kriminalitou a vnitřní bezpečností (Plasser a Sommer 2018: 56). Z uvedených změn voličských preferencí těžila nejvíce právě FPÖ, nebot' se do popředí veřejné diskuse a mediálního zpravodajství dostaly její dlouhodobé programatické priority (Luther 2005: 18-19; Luther 2006: 379). Nárůst podpory Svobodných potvrdily v roce 2015 výsledky voleb do zemských sněmů v Burgenlandu, Horním Rakousku, ve Štýrsku a Vídni (Ulram a Sommer 2016). ${ }^{8}$ V roce 2016 kandidát FPÖ Norbert Hofer zvítězil v prvním kole prezidentských voleb, aby poté ve druhém kole (a opakovaném druhém kole) těsně podlehl bývalému spolkovému mluvčímu Zelených, formálně nezávislému Alexandrovi Van der Bellenovi (Ulram a Sommer 2017). ${ }^{9}$

Nepř́znivý vývoj se počátkem roku 2017 pokusila zvrátit sociální demokracie. Spolkový kancléŕ Christian Kern prezentoval obsáhlý koncept reforem a modernizace Rakouska pod názvem „Plán A pro Rakousko. Program pro blahobyt, bezpečnost a dobrou náladu“ (SPÖ, Plan A). Chtěl tím veřejnosti dát jasně najevo, kdo ve vládě bude určovat budoucí zásadní cíle koalice. $\mathrm{V}$ př́padě, že by nedošlo mezi oběma vládními partnery ke shodě, počítal pravděpodobně již tehdy s mimořádnými volbami. Plán A vyvolal u lidovců značnou nervozitu. Tehdejší předseda ÖVP Reinhold Mitterlehner iniciativu sociálních demokratů ostře kritizoval. Zveřejnění Plánu A zatlačilo lidovce do defenzivy a ÖVP hrozil další pokles voličské př́zně (Müller 2017). K rozpadu vlády sice tehdy ještě nedošlo, nicméně hrozba př̀edčasného konce velké koalice stále patřila mezi reálné varianty dalšího vývoje.

Silné vnitro koaliční pnutí se obnovilo 10. května 2017 v reakci na oznámení předsedy lidovců a vicekancléře Reinholda Mitterlehnera o okamžitém odchodu z politiky. Mitterlehner nesplnil očekávání vedení ÖVP a členské základny. Nedokázal zvýšit preference lidovců ani vystoupit ze stínu sociálně demokratického kanclére Christiana Kerna. V konečném důsledku pouze přispěl k prohloubení dlouhodobé krize ÖVP, která od roku 2002 nevyhrála parlamentní

\footnotetext{
${ }^{8}$ V Burgenlandu zaznamenala FPÖ nárůst o 6 procentních bodů, ve Štýrsku o 16,1, v Horním Rakousku o 15,1 a ve Vídni o 5,5 procentních bodů.

${ }^{9} \mathrm{~V}$ dubnu 2016 obdržel Norbert Hofer 35,05 \% odevzdaných hlasů. V druhém kole mu projevilo důvěru 49,65 \% voličů. V opakovaném druhém kole v prosinci téhož roku obdržel 46,21 \% odevzdaných hlasů.
} 
volby a za poslední dekádu vystřídala celkem čtyři různé předsedy..$^{10}$ Mitterlehner byl od počátku vnímán ve smyslu experimentálního řešení. V př́padě jeho selhání počítala členská základna s nástupem nejmladšího ministra zahraničí v rakouských dějinách Sebastiana Kurze „ve vhodnou dobu“. ${ }^{11}$

Uvedený okamžik podle stratégů ÖVP nastal v květnu 2017 (Müller 2017; Maderthaner 2017: 53; Fritzl 2017; Neuwirth 2017a; Redaktion, Die Presse 11. 5. 2017, Print-Ausgabe). Teprve 32letý Kurz podmínil převzetí funkci předsedy lidovců udělením rozsáhlých kompetencí, aby nemusel, ve srovnání s předchůdci, složitě manévrovat mezi vlivnými zemskými a zájmovými organizacemi ÖVP. ${ }^{12}$ Současně odmítl ze strategických důvodů funkci vicekancléře, která v minulosti straně ve volební kampani způsobila nemalé těžkosti (Fellner 2017). Voliči by si úspěchy vlády identifikovali primárně s kancléřem Kernem a Kurz by v jejich očích zůstal pouze „tím druhým“, čímž by ztratil image dynamického a perspektivního politika.

Nový předseda lidovců se záhy vyslovil pro rozpad velké koalice, nebot’ ji nepovažoval za perspektivní. Vycházel přitom z předpokladu, že dlouhotrvající kooperace dvou stejně silných stran při minimální personální obměně vede k častým rozmíšám, vynuceným kompromisům a vzájemné blokádě. $\mathrm{V}$ předčasných volbách spatřoval možnost v novém „rozdání karet“, z nichž by lidovci vzešli vi̊či potencionálnímu partnerovi značně posílení a mohli tak určit parametry budoucí koaliční smlouvy. Dalším veřejně nevysloveným důvodem pro konání předčasných voleb byla nevýrazná bilance vlády, která by v roce 2018 mohla negativně ovlivnit výsledky důležitých zemských voleb v Dolním Rakousku, Tyrolsku, Korutanech a Salcbursku. ${ }^{13}$

Kancléř Kern sice navenek zpočátku předčasné volby odmítal, když nabídl ÖVP pokračování koalice v podobě reformního partnerství, ve skutečnosti ale od zveřejnění Plánu A počítal spíše s novým „rozdáním karet“ voliči. Pro mimořádné volby se vyslovila rovněž větší část veřejnosti (Kittner 2017a; Hajek 2017: 179), přesto lidovci museli kalkulovat s rizikem, že mohou být voliči „potrestáni““ za záměrné vypovězení velké koalice, podobně jako tomu bylo

${ }^{10} \mathrm{Na}$ základě demoskopického šetření agentury GfK Austria doporučovalo $63 \%$ respondentů, aby v prípadě předčasných voleb vedl lidovce Sebastian Kurz, zatímco pouhých $30 \%$ se vyslovilo pro tehdejšího předsedu Reinholda Mitterlehnera (Plasser a Sommer 2018: 71).

11 Wilhelm Molterer vedl stranu v letech 2007-2008, Josef Pröll (ríjen 2008 - duben 2011), Michael Spindelegger (květen 2011 - srpen 2014 a Reinhold Mitterlehner (srpen 2014 - květen 2017).

${ }^{12} \mathrm{~K}$ roli a vlivu zemských i zájmových organizací u ÖVP viz Müller (2006: 349-353).

13 Výsledek mimořádných parlamentních voleb a následné vytvoření vládní koalice lidovců a Svobodných oběma stranám pomohly. Kromě zemských voleb v Dolním Rakousku, kde lidovci ztratili 1,2 procentního bodu ve srovnání s předešlými volbami v roce 2013 (zde však ÖVP obhájila absolutní většinu $\mathrm{v}$ zemském sněmu a to i navzdory odchodu velmi populárního zemského hejtmana Erwina Prölla; FPÖ naopak posílila o 6,6 procentního bodu) oba subjekty zaznamenaly v zemských volbách Tyrolsku, Korutanech a Salcbursku nárůst přízně elektorátu. 
v letech 1995 a 2008. ${ }^{14}$ Zástupci všech parlamentních stran schválili bez problémů př́ślušný zákon o rozpuštění Národní rady před uplynutím funkčního období. Následně spolkový prezident Alexander Van der Bellen vypsal předčasné parlamentní volby na neděli 15. října 2017.

Rozpad velké koalice, a především zvolení Kurze, prezentovala ÖVP jako konec stagnace, nečinnosti, vzájemných rozmíšek a počátek něčeho nového, pozitivního. Všechny ostatní soupeře tím zatlačila do defenzivy. Vedle předsedy a změny názvu na „Nová Lidová strana“ (Die neue Volkspartei) vyměnila tradiční stranickou barvu černou za tyrkysovou (Maderthaner 2017: 54). Větší otevřenost a modernizaci ÖVP mělo demonstrovat 100 nominovaných kandidátů do Národní rady, kteří nikdy nebyli členy strany nebo nekandidovali za lidovce, ale jsou pro určité oblasti odborníky.

Výměna předsedy ÖVP způsobila bezprecedentní změnu voličských preferencí. Podle průzkumů veřejného mínění stagnovala podpora lidovců před odstoupením Mitterlehnera kolem $21 \%$ dotázaných. ÖVP by se tak musela pravděpodobně spokojit s třetím místem za FPÖ a SPÖ. Po jmenování Kurze do čela ÖVP všechny provedené průzkumy veřejného mínění řadily lidovce na první místo s podporou v rozmezí 31-33\% respondentů. Druhá sociální demokracie se pohybovala mezi 26-28 \%, třetí Svobodní nejvíce ztratili ve prospěch lidovců, když jim sociologická šetření přisuzovala podporu 24-26\% dotazovaných (Seidl 2017a; Kittner 2017a; Redaktion, Profil 20. 5. 2017; Plasser a Sommer 2018: 75).

Politologové Fritz Plasser a Franz Sommer pro tuto náhlou demoskopickou změnu používají príléhavé pojmenování „Kurz-Effekt". Nový předseda ÖVP oslovil zhruba 480000 voličů, kteři při posledních parlamentních volbách nepodpořili lidovce. $47 \% \mathrm{z}$ nich projevilo důvěru subjektům tzv. třetího tábora (Svobodná strana Rakouska, Svaz pro budoucnost Rakouska a Tým Stronach), $15 \%$ podpoŕilo SPÖ, $9 \%$ liberální Nové Rakousko (Das Neue Österreich und Liberales Forum, NEOS), 8 \% Zelené (Die Grünen - Die Grüne Alternative) a $21 \%$ patŕilo do skupiny nevoličů. Kurz přesvědčil především ženy, voliče střední a starší generace bydlící v menších městech a na venkově (Plasser a Sommer 2018: 75).

Průzkumy veřejného mínění před začátkem intenzivní fáze volební kampaně dávaly za určitých okolností možnost bojovat o prvenství ve volbách všem třem velkým stranám - lidovcům, sociální demokracii a Svobodným, tedy předpovídaly situaci, která neměla do té doby v rakouských dějinách obdoby. Současně bylo evidentní, že ve stínu souboje těchto politických subjektů budou menší politické strany jen velmi obtížně hledat profilující téma a svébytnou názorovou pozici.

\footnotetext{
${ }^{14}$ Lidovecký politik Wolfgang Schüssel vyvolal dvakrát mimořádné parlamentní volby. Zatímco v roce 1995 ÖVP oslabila, o sedm let později zaznamenala výrazný nárůst hlasů. V červenci 2008 vypověděl tehdejší vicekancléř a předseda ÖVP Wilhelm Molterer koaliční smlouvu se sociální demokracií slovy: „Es reicht“. V následujících předčasných parlamentních volbách lidovci dosáhli historicky nejhoršího výsledku (Hajek et. al. 2008: 1-2; Šepták 2008; Pöttler 2008; Ulram 2009; Filzmaier 2009; Kriechbaumer 2016: 889-925).
} 
Nejvíce problémů se startem volební kampaně měli Zelení. Ještě ani nedozněly spory mezi stranickým vedením a mládežnickou organizací ${ }^{15}$ když 17. května zveřejnil renomovaný německý týdeník Die Zeit překvapující zprávu o chystaném odstoupení Evy Glawischniggové z pozice předsedkyně (spolkové mluvčí) Zelených (Riedl a Gasser 2017; Sittinger, Jungwirth a Gigler 2017). Glawischniggová tím reagovala na stále vzrůstající vnitrostranickou kritiku, klesající popularitu a přetrvávající zdravotní problémy (Strobl 2017: 120-121; Redaktion, Der Standard 18. 5. 2017). Zelení vyřešili vzniklé personální vakuum pragmatickým rozdělením klíčových rolí. Předsedou parlamentního klubu se stal Albert Steinhauser, funkci spolkové mluvčí převzala na spolkové úrovni nepř́lišs známá, zato však perspektivní tyrolská politička Ingrid Felipeová. Pozici lídra pro parlamentní volby zaujala zkušená Ulrike Lunaceková (Ettinger 2017; Föderl-Schmidt 2017; Šepták 2017) Místopředsedkyně Evropského parlamentu si stanovila ambiciózní cíl pro volby do Národní rady v podobě zisku dvojciferného výsledku a zároveň jasně deklarovala ochotu strany participovat na vládě složené ze sociální demokracie a NEOS (Metzer 2017).

Proces vnitřní konsolidace Zelených vážně narušil 25. června 2017 spolkový kongres strany za účelem nominace kandidátů do parlamentních voleb. Došlo zde k eskalaci sporu mezi stranickým vedením a jedním ze zakládajících členů Zelených Peterem Pilzem. Známý bojovník proti korupci a za odpovědné nakládání $\mathrm{s}$ veřejnými prostředky již předtím vyčítal straně zkostnatělost, odtažitost od starostí „obyčejných lidí“ a neschopnost adekvátně reagovat na aktuální témata - např́klad migrační krizi nebo nutnou reformu vzdělání. Poté, co nezískal potřebnou důvěru delegátů v souboji o čtvrté místo na spolkové kandidátce, odmítl usilovat o mandát v Národní radě prostřednictvím preferenčních hlasů (Die Grünen 2017a; John 2017; Noll 2017). Bezprostředně po kongresu avizovaný konec v politice si ovšem velmi rychle rozmyslel, když začal přpravovat s blízkými spolupracovníky založení nové strany (Dimmel a Noll 2017: 103).

Koncem července skutečně vznikl nový politický subjekt s názvem „Kandidátka Peter Pilz“ (Liste Peter Pilz, PILZ). Podle Pilze se nemělo jednat o klasickou politickou stranu se stranickým aparátem a politickým programem, nýbrž o „médium pro účast občanư“, kde každý kandidát osobně garantuje prosazování svého programu, bude-li zvolen do Národní rady (PILZ 2017a: 2; PILZ 2017b; Prior 2017a). ${ }^{16}$ PILZ mohla těžit ze značných rétorických schopností a nemalých zkušeností svého zakladatele a jednoho z nejznámějších současných rakouských politiků. Od počátku svého vzniku i během volební kampaně byla stranou jednoho muže. Peter Pilz představoval lídra, ústřední postavu a zároveň

\footnotetext{
15 Spor vznikl ohledně voleb do samosprávných orgánů vysokých škol v Linci a Štýrském Hradci. Způsobil vznik dvou navzájem konkurujících si uskupení hlásících se ke straně Zelených. Vedení Zelených koncem března 2017 vyloučilo mládežnickou organizaci ze své organizační struktury a založilo novou platformu (Temel 2017).

${ }^{16}$ Kandidátka Peter Pilz má pouhé čtyři členy.
} 
politický program v souladu s volebním heslem „Mnozí vládnou, jeden kontroluje. Peter Pilz" (PILZ 2017c). Všechny tyto skutečnosti ji mohly pomoci kompenzovat malý rozpočet pro volební kampaň financovaný výlučně prostř̌ednictvím darů (Sickinger 2017: 230) ${ }^{17}$ a absenci v hojně sledovaných diskusích na veřejnoprávní televizi ORF. ${ }^{18}$ Renomovaný rakouský politolog Fritz Plasser přišel již koncem července s odvážnou domněnkou, že PILZ nejen překoná $4 \%$ hranici potřebnou na spolkové úrovni pro vstup do Národní rady, ale připustil také možnost lepšího volebního výsledku než v př́ípadě Zelených. Potencionální voliče nové strany spatřoval jednak u Zelených, a jednak také u sociální demokracie (APA, Kleine Zeitung 27. 7. 2017).

Koncem června oznámil úmysl nekandidovat v blížících se parlamentních volbách Tým Stronach (Fritzl a Aichinger 2017). Jednalo se o bezprecedentní krok v rakouských dějinách, nebot' dosud každá strana zastoupená v Národní radě učinila alespoň pokus o opakované dosažení parlamentní relevance. Úspěšný podnikatel Frank Stronach vstupoval do politiky s nejvyššími ambicemi. Sliboval voličům nové tváře a příchod odborníkủ. Po sérii úspěchů v zemských volbách v roce 2013 následovalo na podzim téhož roku v boji o mandáty v Národní radě zklamání. ${ }^{19}$ Vinou katastrofálních televizních vystoupení Franka Stronacha získala jeho strana 5,7 \% odevzdaných hlasů (Martin 2015; Hofer 2014: 7-9). Po tomto nezdaru ztratil podnikatel o politiku zájem. Po pouhých třech parlamentních schůzích opustil Národní radu, následně přestal stranu finančně podporovat. Bez svého zakladatele a štědrého donátora oslabovaly Tým Stronach silné vnitřní spory jak na spolkové, tak na zemské úrovni (Filzmaier 2014; Böhmer 2014; Marchart 2015; Metzger a Lindorfer 2016). Pokusy o restart ztroskotaly. Strana nedokázala najít ani profilující téma, ani dostatečně charismatického a kompetentního lídra. Ukázalo se, že se v podstatě jednalo o volební spolek obdivovatelů a př́znivců úspěšného podnikatele.

Vývoj Týmu Stronach nápadně prripomíná osud Svazu pro budoucnost Rakouska. Ještě v roce 2013 dokázal získat 3,5 \% odevzdaných hlasů. Bez svého zakladatele a ústřední postavy - charismatického, leč kontroverzního Jörga Haidera - se postupně propadal do bezvýznamnosti. V mimořádných parlamentních volbách v ř́ijnu 2017 vcelku očekávaně nekandidoval. Na volebním trhu se ve srovnání s rokem 2013 obrazně řečeno nacházelo přes $9 \%$ voličů, kteří bud’ hledali nový politický domov, nebo rozšíríli řady nevoličů.

\footnotetext{
17 Rozpočet SPÖ činil podle údajů strany 5,03 milionů eur, zatímco PILZ se musela spokojit s 282000 eur (Sickinger 2017: 233).

18 Rakouská veřejnoprávní televize ORF zve k účasti $\mathrm{k}$ televizním diskusím v hlavním vysílacím čase pouze strany, které mají status parlamentního klubu Národní radě. Kandidátka Petera Pilze proti tomuto postupu neúspěšně protestovala (Kaltenbrunner 2017).

${ }_{19} \mathrm{~V}$ březnu 2013 ve volbách do korutanského zemského sněmu dosáhl Tým Stronach 11,18 \%, v Dolním Rakousku 9,84 \%, dubnu 2013 v Tyrolsku 3,36 \%, v květnu téhož roku 8,34\% v Salcbursku odevzdaných hlasů.
} 
$S$ ohledem na jejich preference se dalo předpokládat, že podpoří především ÖVP a FPÖ (SORA 2008: 17-18, 20; SORA 2013: 2-4; Höbelt 2014: 67). Uvedená skutečnost spolu se vznikem Kandidátky Petera Pilze přinášela určitou výhodu pro lidovce a Svobodné, zatímco SPÖ a Zelení museli počítat spíše s úbytkem hlasů (Uhl 2017: 65).

Nejmenší opoziční strana zastoupená v Národní radě - liberální Nové Rakousko - vystupovala od počátku volební kampaně konsolidovaným a jednotným dojmem. Na základě výsledků primárních voleb vedl liberály do parlamentních voleb dosavadní předseda NEOS Matthias Strolz ${ }^{20}$ druhé místo zaujala Irmgard Grissová. Bývalá předsedkyně Nejvyššího soudu se na jaře 2016 ucházela o funkci spolkového prezidenta a v nabité konkurenci si nevedla vůbec špatně, když obdržela téměř $19 \%$ odevzdaných hlasů. Dokázala voličům nabídnout alternativu $\mathrm{k}$ zástupcům etablovaných politických stran. Předvedla zdařilou předvolební kampaň, během níž získala image kandidátky, která má dostatečné profesní zkušenosti, ale zároveň není zatížena každodenními politickými tahanicemi. Získaný nemalý potenciál chtěla Grissová využít k pokračování politické kariéry. Když ztroskotaly rozhovory mezi Sebastianem Kurzem, Matthiasem Strolzem a Irmgard Grissovou o vytvoření společné volební platformy (Donig 2017: 91-93; Nowak a Stuhlpfarrer 2017), zvolila spolupráci se stranou, která ji otevřeně podpořila již v prezidentských volbách (Kittner 2017b). $S$ jejím př́chodem ambice NEOS výrazně stouply. Liberálové doufali, že jim Grissová zabezpečí nejenom vstup do Národní rady, ale podle Strolze mělo být cílem dosažení dvouciferného výsledku (Bayrhammer 2017a; Bayrhammer 2017b).

\section{Počátek volební kampaně}

Politologové a straničtí stratégové správně spatřovali v mocenské rošádě lidovců impuls k př́ečasným volbám. Kampaň v souvislosti s nimi zahájili velmi záhy, 15. května 2017, Svobodní s heslem „S ním Rakousko může vždy počítat, zatímco jiní jsou zdánlivě chytř̌ješ́ krátce před volbami“. Byla zaměřená na předsedu strany Heinze-Christiana Stracheho a kritiku vládních stran. SPÖ a ÖVP údajně v několika důležitých otázkách (azylová politika, hrozba islamizace a podpora rodin) zdánlivě souhlasily s konzistentně prosazovanými návrhy FPÖ, nicméně ve skutečnosti o žádné konstruktivní řešení neusilovaly, jak ukazují konkrétní zasedání Národní rady (FPÖ 2017a). Svobodní sáhli ke strategii využívané od dob Jörga Haidera: dlouhá volební kampaň s cílem mobilizace co největšího počtu př́znivců, její značná personalizace zaměřená na lídra strany a kritika velké koalice v profilujících tématech FPÖ (např́klad azylová politika nebo ochrana vnitřního pracovního trhu) (Marquart 2013).

20 Nové Rakousko uplatnilo pro sestavení kandidátky unikátní trojstupňový systém primárních voleb. V prvním kole vybírali kandidáty občané prostřednictvím elektronického hlasování, v druhém kole rozhodovalo předsednictvo a ve třetím kole členská základna (NEOS 2017a). 
První z parlamentních stran, v reakci na razantní nástup lidovců, prezentovala programové priority pro ř́jinové parlamentní volby sociální demokracie. Prostřednictvím sedmi podmínek pro uzavření budoucí koalice zveřejněných 14. června navazovala na Plán A. Zahrnovaly daňovou reformu včetně ukončení „Zvláštních práv“ pro velké koncerny, od roku 2019 minimální mzdu ve výši 1500 eur bez povinného zdanění, možnost celodenní péče o děti od prvního roku jejich života, 5000 nových učitelů a 2500 nových policistů, zajištění financování péče prostřednictvím zavedení dědické daně u dědictví př́sahující jeden milion euro, bezpečnou penzi, modernizaci veřejné správy a slib vytvoření 200000 nových pracovních míst v nadcházejícím funkčním období (SPÖ 2017b).

ÖVP naopak od začátku zvolila značnou personalizaci volební kampaně, když $\mathrm{v}$ rámci veřejné prezentace prripravovaného volebního programu nechala prostřednictvím plakátů zobrazit Sebastiana Kurze v diskusi s „obyčejnými“ lidmi o nových cestách pro Rakousko. Lidovci pritom zdůraznili prostřednictvím generální sekretářky Elisabeth Köstlingerové snahu soustředit se na vlastní programové priority $\mathrm{v}$ podobě zvýšení hospodářské konkurenceschopnosti Rakouska, reformy sociálního systému a posílení bezpečnosti, přičemž odmítli použít vioči ostatním politickým stranám negativní kampaň (Redaktion, Tiroler Tageszeitung 24. 6. 2017; Jungwirth 2017).

Období letních měsíců využil Kurz k představení osobností na prvních místech kandidátky. Ve zhruba týdenních intervalech prezentoval bývalého člena Zelených Efgani Domeze, organizátorku tradičního bálu ve vídeňské Opeře Marii Großbauerovou, rakouskou rekordmanku ve skoku o tyči Kiru Grünbergovou, matematika Rudolfa Taschnera nebo vídeňského policejního viceprezidenta Karla Mahrera. Největší posilou se však jevil bývalý předseda Účetního dvoru Josef Moser, odborník na odpovědné nakládání s veřejnými financemi a reformu veřejné správy.

\section{Volební programy jednotlivých stran}

Počátkem srpna zveřejnila sociální demokracie jako první z parlamentních stran volební program, přičemž se jednalo o mírně upravenou verzi Plánu A. Mezi jeho hlavní pilíŕe patřilo snížení daní, opatření na pracovním trhu a penze (SPÖ 2017a: 28-31, 34-35, 50-53). Zejména slib zvýšení minimálních penzí a omezení „penzijních“ privilegií měl pomoci mobilizovat tradiční voliče strany nad 50 let (SPÖ 2017a: 122-127). Ve srovnání s ostatními politickými stranami navrhovala SPÖ podstatnou změnu ústavy v podobě okleštění pravomocí spolkového prezidenta, podle níž by vítězná strana automaticky nominovala spolkového kancléře a první zkusila sestavit vládu (SPÖ 2017a: 203). Za zajímavý a v prostředí předvolební kampaně unikátní lze považovat návrh na zavedení „muzejní neděle“, tedy vstup zdarma do všech spolkových muzeí v závěru každého týdne (SPÖ 2017a: 179-180). 
Lidovci prezentovali volební program postupně ve třech etapách. Zvolili tím na rakouské poměry unikátní strategii a stejně jako $\mathrm{v}$ prrípadě představení zajímavých kandidátů zdařile upoutali pozornost médií a veřejnosti. $\mathrm{V}$ každé části dokázali vystihnout témata, která rakouská veřejnost považovala za důležitá. První část programu pojednávala o daňových úlevách (ÖVP 2017a: 24-36) a reformě sociálního systému. Lidovci požadovali stanovit sociální pomoc v podobě tzv. zaručených minimálních prostředků orientovaných na potřeby konkrétní osoby (tzv. Mindestsicherung) jednotně na 1500 euro měsíčně. Žadatelé, kterým byl přiznán $\mathrm{v}$ alpské republice azyl, by podle návrhu ÖVP museli počítat se zkrácenou mírou podpory v délce pěti let v maximální výši 565 euro (ÖVP 2017a: 64-68).

V druhé části programu lidovci převzali tradiční téma Svobodných, když za základní předpoklad pro bezproblémovou integraci do většinové společnosti a uplatnění na pracovním trhu pokládali dostatečnou znalost německého jazyka. Pro děti, které těmito dovednostmi nedisponují, mají být zrrízené nejen speciální tř́dy bez ohledu na věk, ale i speciální kurzy (ÖVP 2017c: 48-49).

Poslední, třetí část volebního programu, nejvýrazněji reflektovala tehdejší programatické preference rakouského elektorátu. Lidovci v něm požadovali ukončení ilegální migrace a odmítali stanovení horní hranice počtu migrantů, které by Rakousko muselo ročně přijmout. ÖVP $\mathrm{v}$ této souvislosti neopomněla připomenout Kurzovu aktivitu v otázce zavření balkánské migrační cesty. Pro prristěhovalectví do Rakouska chtěla zavést bodový systém, jenž by zohlednil poptávku alpské země po vysoce kvalifikovaných pracovních silách pro určité profesní segmenty. Dále lidovci požadovali reformu evropského azylového práva a zvýšenou kontrolu vnějších hranic Evropské unie (ÖVP 2017c: 18-21). ÖVP rovněž odmítala politický islám a vytváření „paralelních“ společností (ÖVP 2017c: 22-27). Poslední část volebního programu věnovala ÖVP bezpečnosti: Zamýšlela posilit policejní sbor a spolkové vojsko, prosadit bezpečnostní opatření se zaměřením na kyberkriminalitu, nebo zpř́snit sazby pro vybrané trestné činy, např́klad při násilí a provokacích vưči demokracii, právnímu státu, náboženství, nebo společenským skupinám (ÖVP 2017c: 50-57).

Svobodná strana Rakouska prezentovala volební program dvoufázově. Nejprve v polovině srpna zveřejnila hospodářskou část $\mathrm{s}$ daleko širším tematickým přesahem s podtitulem „Spravedlnost - svoboda - pokrok“. $\mathrm{V}$ intencích předchozích let ostře kritizovala činy velké koalice, jejíž politika podle FPÖ vedla k vysokým daním, snížení hrubého domácího produktu, k růstu nezaměstnanosti a ztrátě konkurenceschopnosti Rakouska na mezinárodních trzích (FPÖ 2017c: 5-11). Druhá část programu prezentovaná 13. záŕí dvojkou kandidátky Norbertem Hoferem obsahovala celkem 100 v drtivé většině již v minulosti několikrát opakovaných návrhů k překonání „krize spravedlnosti“ (FPÖ 2017f). Vedle restriktivní migrační politiky a obnovení hraničních kontrol nechyběl ani požadavek posílení nástrojů prrímé demokracie podle vzoru Švýcarska, př́sné zachování neutrality Rakouska i všeobecné branné povinnosti, či 
stanovení minimální mzdy do výše 1500 euro měsíčně. Ve srovnání s ostatními politickými soupeři přišli Svobodní se slibem garance používaní motorových vozidel s dieselovým spalovacím motorem do roku 2050 (FPÖ 2017f).

Zeleným nechyběla při sestavování programu odvaha a určitá míra vizionářství, které však nedokázaly vystihnout tehdejší programatické priority rakouského elektorátu. Ve srovnání s ostatními politickými soupeři požadovali s platností od roku 2030 zákaz nově prihhlásit automobil se spalovacím motorem pro provoz na pozemních komunikacích (Die Grünen 2017b: 31). Velmi ambiciózně a vostrém protikladu ke slibu FPÖ působil plán kompletního přechodu Rakouska na obnovitelné zdroje energie do roku 2050 (Die Grünen 2017b: 26). Migrační otázku zamýšleli Zelení vyřešit pomocí zavedení jednotných evropských azylových pravidel. Př́nesly by vznik „Azylové kanclére Evropské unie“ za účelem koordinace všech potřebných náležitostí, včetně dohledu nad „spravedlivým“ rozdělením migrantů mezi členské země Evropské unie (Die Grünen 2017b: 40).

Velmi stručný volební program prezentovalo liberální Nové Rakousko. Jednalo se o kompilát již dříve vyslovených návrhů bez sebemenších př́kvapení. Naznačilo v něm „radikální léčbu“ pro alpskou republiku. Zahrnovala redukci státní podpory politických stran o polovinu a okamžité zrušení „nesmyslně drahých zaopatřovacích míst jako městský rada bez portfeje nebo vicestarosta“. Ušetřené prostř̌edky chtělo NEOS využít pro financování vzdělání a péče. Navrhovaná opatření $\mathrm{v}$ oblasti daní měly přinést snížení daňové zátěže pro právnické a fyzické osoby ve výši osm miliard euro ročně. Liberálové zamýšleli zavést, bez uvedení podrobností, flexibilní model penzí a konec „privilegovaných penzí “21 (NEOS 2017b: 3). Podobně jako FPÖ zamýšleli zrušit povinné členství v Rakouské komoře práce a Rakouské hospodářské komoře (NEOS 2017b: 6). Liberálové hodlali zavést dvouinstanční azylové ř́zení s maximální dobou trvání v délce 180 dnů, od něhož očekávali efektivnější a rychlejší pomoc žadatelům o azyl (NEOS 2017b: 7).

Ze srovnání volebních programů všech relevantních stran vyplývá značná programová shoda mezi ÖVP a FPÖ. Obě strany navrhovaly snížení daní, byly proti zavedení darovací daně, vyslovily se pro podporu větší flexibility pracovní doby a právního nároku otce mít možnost zůstat jeden měsíc doma s čerstvě narozeným dítětem. Společný odmítavý názor zastávaly rovněž $\mathrm{v}$ otázce zrovnoprávnění registrovaného partnerství pro homosexuální páry s institucí manželství. Největší rozdíly panovaly mezi oběma stranami v sociální politice a postoji vůči Evropské unii: Svobodní požadovali zavedení minimální penze ve

${ }^{21}$ Tzv. privilegované penze patř́ mezi častá politická témata. V praxi se jedná „luxusní důchody“ pro některé penzionované státní funkcionáře (vybraní bankéri a politici), které několikanásobně překračují výši průměrného starobního důchodu v Rakousku. 
výši 1000 euro a minimální mzdy ve výši 1500 euro měsíčně, zatímco lidovci o obojím mluvili konkrétně jen neradi.

Naopak několik zásadních neshod nabízí komparace programů sociální demokracie a lidovců. V hospodářské politice zamýšleli oba subjekty daňovou reformu, ovšem SPÖ striktně odmítla koncept lidovců jako „daňové dárky ÖVP pro superbohaté“ (SPÖ 2017h). V otázce zavedení dědické daně, horní hranice pro růst nájemného nebo zrovnoprávnění registrovaného partnerství s institucí manželství zastávali diametrálně odlišná stanoviska (SPÖ pro, ÖVP proti). Lidovci navrhovali reformu Mindestsicherung, sociální demokraté nikoli. ÖVP odmítala návrh SPÖ, aby migranti mohli žádat o azyl již ve sběrných táborech v severní Africe.

Varianta vládní spolupráce SPÖ a FPÖ narážela na dlouhodobé odmítání z řad sociální demokracie, byt' ve spolkové zemi Burgenland fungovala od roku 2015. Obě strany našly programovou schodu v otázce zvýšení minimální penze a zavedení minimální mzdy nebo vomezení př́stupu cizinců na rakouský pracovní trh. SPÖ a FPÖ naopak rozdělovaly opačné názory na zrovnoprávnění registrovaného partnerství s institucí manželství, na povinné kvóty pro ženy v dozorčích radách, a také společné vzdělávání dětí (SPÖ pro, FPÖ proti). Odlišně byly $\mathrm{v}$ předvolebních programech prezentovány rovněž představy o vývoji Evropské unie. Zatímco socialisté chtěli další prohloubení evropské integrace, Svobodní naopak návrat některých kompetencí členským státům.

U dalších možných koaličních variant ve složení SPÖ-Zelení-NEOS nebo ÖVP-Zelení-NEOS nebylo jasné, zda budou alespoň v čistě matematické rovině vưbec možné. ${ }^{22}$

\section{Intenzivní volební kampan̆}

Sociální demokracie vstupem do intenzivní volební kampaně počátkem srpna propojila dưraz na sociální témata se zaměrením na kompetence a dosavadní výsledky kancléře Christiana Kerna. Prezentovala prritom v souvislosti s první vlnou plakátů účelově kontroverzní heslo „Vezměte si, co Vám patřiı“. Chtěla tím odvést pozornost voličů od problematiky migrace a bezpečnosti k ostatním tématům (SPÖ 2017c; Uhl 2017: 69) - např́klad daňové reformě, právnímu nároku na celodenní mateřskou školu, bezpečné penzi nebo slibu 5000 nových učitelů do škol a 2500 nových policistů do ulic (SPÖ 2017e).

Při oficiálním startu intenzivní fáze volební kampaně 7. září 2017 ve Štýrském Hradci prrišla s druhou vlnou plakátů s mottem „Změna s odpovědnostíc, s cílem zdůraznit Kernovy kompetence $\mathrm{v}$ hospodářské a sociální oblasti a prezentovat pokrok Rakouska během jeho vlády (SPÖ 2017f). Poslední třetí vlnou plakátů

\footnotetext{
${ }^{22}$ Kandidátka Petera Pilze od počátku dala najevo, že bez ohledu na výsledek voleb bude plnit roli opozice.
} 
pokračovala v značné personalizaci kampaně. Kern byl zobrazen s dětmi předškolního věku, čímž chtěla strana zdůraznit, že i nadále je připravena pracovat pro perspektivní budoucnost nastupující generace. Kanclér v kampani zdůrazňoval hospodářský vzestup Rakouska během posledního roku, který umožnilo „každodenní nasazení a tvrdá práce Rakušanů a Rakušanek“ a „důsledná politika se sociálně demokratickým rukopisem“. Voličům dále slíbil daňové úlevy pro malé a střední podniky, a „spravedlivý daňový př́spěvek“, tj. vyšší daně pro velké mezinárodní společnosti s milionovým jměním. Takto získané prostředky chtěl investovat do školství, nemocnic a „technologií budoucnosti““. (SPÖ 2017g).

Lidovci pokračovali během intenzivní volební kampaně $\mathrm{v}$ značné personalizaci. ÖVP označila volby do Národní rady za referendum o novém politickém stylu spočívajícím ve věcnosti, ukončení minimalistických kompromisů a vzájemné blokády. Strana se snažila představit Sebastiana Kurze jako člověka, který neztratil schopnost naslouchat druhým a zajímá se o jejich názor; dokáže přitom najít odvahu pojmenovat problémy a navrhnout jejich řešení, jako naprŕklad uzavření tzv. balkánské trasy. V souladu s volebním programem prosadí pro všechny občany Rakouska „novou spravedlnost" vycházející ze změn sociálního systému, „nový blahobyt" dosažený prostřednictvím daňové a správní reformy a „novou bezpečnost“ spočívající v zastavení nekontrolovatelné migrace a důsledném dodržování rakouských pravidel a zákonů, přičemž o základních hodnotách, na kterých je alpská země postavena, není možné vyjednávat (ÖVP 2017d).

$\mathrm{V}$ intencích zdůraznění nového image přestala strana záměrně užívat tradiční zkratku ÖVP, která se objevila až v samotném závěru kampaně v rámci třetí vlny plakátů (APA, Der Standard 28. 9. 2017). Sebastian Kurz v její finální fázi několikrát varoval před údajnými tajnými rozhovory mezi SPÖ a FPÖ o utvoření společné vládní koalice. $\mathrm{V}$ př́padě, že ÖVP nezvítězí s dostatečným náskokem, měl hrozit koaliční typ spolupráce uplatňování v praxi od roku 2015 ve spolkové zemi Burgenland (ÖVP 2017d, e, f). Jak socialisté, tak lidovci zdařile odhadli důležitou roli strategického hlasování s ohledem na budoucí koaliční spolupráci a shodně varovali prred kooperací dvou nejvážnějších soupeřũ.

$\mathrm{Na}$ rozdíl od předchozích parlamentních voleb postavili Svobodní kampaň na dvojici lídrů. Předsedu strany Heinze Christiana Stracheho doplňoval Norbert Hofer (FPÖ 2017e). Třetímu předsedovi (čili druhému místopředsedovi) Národní rady se podařilo během prezidentských voleb oslovit především nespokojené voliče lidovců mimo velká města, navíc Hofer byl pro př́znivce ostatních stran přijatelnější než kontroverzní Strache. Oba tak absolvovali v podstatě samostatnou volební kampaň, přičemž na nejdůležitějších shromážděních vystupovali společně (Kickl 2017: 79-80).

Svobodní zahájili intenzivní volební kampaň 21. srpna vystoupením lídra a předsedy strany Stracheho v rámci „letních rozhovorư“ na veřejnoprávní 
televizi ORF. Celkově vyzněla ve srovnání s předchozími roky méně kontroverzně a s pokusem o určité humorné ladění, i když např́klad v rámci kampaně ve Vídni nechyběly poukazy na hrozbu islamizace Rakouska, přistěhovalectví způsobující rostoucí kriminalitu a existenci „paralelních kultur“ (FPÖ 2017d: 2-5). Ústředním motivem kampaně FPÖ bylo pranýřování „krize spravedlnosti“, tj. stavu způsobeného nečinností, vzájemnými rozmíškami a nereálnými sliby velké koalice. Jediný způsob, jak posunout Rakousko vpřed, bylo „zbavit se červeno-černého balastu“, tedy vyslovit nedůvěru současnému kabinetu (FPÖ 2017b). Svobodní se v kampani zaměřili na reformu sociálního systému ve prospěch rakouských státních občanů, snížení daní a byrokracie, větší respekt k osobnímu vlastnictví s odmítnutím zavedení dědické daně, zvýšení bezpečnosti a častější využívání nástrojů prímé demokracie podle vzoru Švýcarska (FPÖ 2017g, h, i).

Volební lídr Heinz Christian Strache vystupoval na rozdíl od předchozích let v kampani umírněně a státnicky. Změna strategie nápadně připomínala postup Jörga Haidera v roce 2008, který takto dosáhl nečekaného úspěchu. ${ }^{23}$ Cílem Stracheho bylo převzít vládní odpovědnost a zabránit tak dalšímu pokračování velké koalice. Ve srovnání s rokem 2013 nevznesl nárok na funkci kancléře a pripustil, že by zaujal pozici vicekancléře ve vládě vedené Sebastianem Kurzem (Redaktion, Kurier 1. 10. 2017).

Liberální Nové Rakousko navázalo na úspěšnou volební kampaň z parlamentních voleb 2013. Chtělo přesvědčit voliče, aby nedali svůj hlas „starým stranám“, jež budou po volbách opět hledět na vlastní prospěch, ale tentokrát podpořili liberály. V kampani se NEOS soustředilo na reformu vzdělání, vylepšení podnikatelského prostředí, daňové úlevy, flexibilní model penzí a konec „luxusních penzí“. Ve srovnání s jinými relevantními stranami věnovali více pozornosti otázce transparentnosti v politice. Navrhli snížení státní podpory stranám o polovinu, odstranění zbytečných „zaopatřovacích“ míst ve veřejné správě, zprrístupnění stranických financí 365 dní v roce a vytvoření veřejně přístupné databáze o financování stran (NEOS 2017c, d). NEOS kombinovalo ve volební kampani důraz na jednotlivá klíčová témata a stranické lídry Matthiase Strolze a Irmgard Grissovou.

Zelení se ve volební kampani soustředili na tradiční témata: ochranu životního prostředí, sociální spravedlnost, rovnoprávnost mužů a žen, dostupné bydlení, zrovnoprávnění registrovaného partnerství s institucí manželství a prohloubení evropské integrace ve smyslu federalizace Evropské unie. Tváří volební kampaně byla zkušená Ulrike Lunaceková (Die Grünen 2017c, 2017d). Kromě ochrany životního prostředí nedokázali zaujmout dostatečně samostatnou pozici a príliš často zastávali totožné stanovisko s prioritami sociální demokracie,

\footnotetext{
${ }^{23}$ Svaz pro budoucnost Rakouska získal v parlamentních volbách v roce 2008 nečekaně 10,7 \% odevzdaných hlasů.
} 
např́ílad v otázce nájemného, zavedení dědické daně a minimální mzdy nebo prohloubení evropské integrace. Pokus o vymezení vi̊či SPÖ tak vyzněl do ztracena (APA, Die Presse 5. 10. 2017). Úspěch nepřineslo ani odmítnutí návrhů FPÖ a ÖVP na zpř́snění migrační a azylové politiky, ani varování před strategickou volbou s ohledem na možné koaliční varianty (Pechar 2017; Linddorfer a Gaul 2017). Voliči totiž v důsledku vnitřní nejednotnosti strany pochybovali, zda Zelení budou v Národní radě disponovat odpovídajícím zastoupením schopným ovlivnit možné povolební koaliční varianty.

Kandidátka Petera Pilze předvedla ve srovnání s ostatními politickými soupeři, kteři měli podle průzkumů veřejného mínění šanci na dosažení parlamentní relevance, zcela odlišnou volební kampaň. V rakouském tisku nezveřejnila jediný předvolební inzerát a prezentovala pouze jeden volební plakát. Zahájení, přidání nálepky „100\% kontrola“ na plakát a ukončení volební kampaně probíhalo symbolicky vždy před budovou rakouského parlamentu ve Vídni. Strana vsadila na Pilzovy rétorické a mediální schopnosti, kontaktní kampaň a prezentaci na sociálních sítích, především na Facebooku a Twitteru.

Volební kampaň jako celek charakterizovalo dosud nebývalé množství televizních konfrontací mezi volebními lídry. Kromě veřejnoprávní debaty na kanálu ORF probíhaly debaty na soukromoprávních televizích Puls 4, ATV, Servus TV a ve srovnání s rokem 2013 i nově oe24-TV. Značný prostor věnovala kandidujícím stranám tištěná médi, $\mathrm{k}$ prezentaci rozmanitých názorů sloužily rovněž sociální sítě. Podle předvolebních průzkumů zůstávali favority voleb lidovci (Lindorfer a Hager 2017). Hlavní vyzyvatelé, SPÖ a FPÖ, spoléhali na nevýrazné a nejisté Kurzovo vystoupení v televizních debatách a upozorňovali na názorové obraty předsedy lidovců ohledně islámu a azylové politiky. Kurz však zdařilou změnou image strany dokázal přesvědčit voliče o tom, že přináší změnu k lepšímu, ačkoliv patřil mezi členy vlády od roku 2011.

Především sociální demokracie doufala v opakování historie. V roce 2006, kdy $\mathrm{v}$ předvolebních průzkumech ztrácela na lidovce, nakonec ve volbách ke všeobecnému překvapení zvítězila. Mezi strůjce nečekaného úspěchu patřil izraelský volební stratég Tal Silberstein. Doporučil SPÖ koncentrovat se na její tradiční témata, jako jsou např́klad zaměstnanost, penze nebo sociální spravedlnost. Silberstein tehdy neváhal využít negativní kampaně vůči ÖVP, kdy sociální demokracie pranýřovala podezřelý a dodnes nevyjasněný nákup stíhacích bitevníků Eurofighter, který šel na vrub vlády lidoveckého kanclére Wolfganga Schüssela (Aichinger 2017). Po výše uvedených tradičních tématech sáhla SPÖ rovněž v loňské volební kampani, s jedním podstatným rozdílem.

$\mathrm{Na}$ přelomu srpna a záři vypukla aféra s falešnými facebookovými profily. První, „Pravda o Sebastianu Kurzovi“, představoval lídra lidovců jako stoupence otevřené migrační politiky, loutku v rukách bývalého kancléře Schüssela a politika připravujícího pokračování velké koalice. Kladl si za cíl přesvědčit někdejší př́znivce FPÖ, aby nepodpořili ÖVP. Druhý profil, „My pro 
Sebastiana Kurze“. měl naopak odradit liberální voliče. Především první z uvedených profilů obsahoval př́spěvky s rasistickým a antisemitským podtextem. Stopy negativní kampaně za hranicemi rakouské politické kultury vedly kSPÖ, konkrétně ke skupině lidí kolem volebního stratéga Tala Silbersteina, mezitím zatčeného v Izraeli kvůli podežrení z trestné činnosti. Aféra Silberstein vrhla na sociální demokracii nepříznivé světlo. Zdálo se, že strana nedokáže věcně argumentovat a místo toho chce zvítězit za každou cenu (Tóth 2017; Bauer 2017; Thalhammer 2017).

V reakci na zveřejněné informace odstoupil 30. září vedoucí volební kampaně SPÖ Georg Niedermühlbichler. Navzdory různým předpovědím o kolapsu SPÖ se socialisté nakonec dokázali konsolidovat (Kopeinig 2017). Aféra sice prrispěla $k$ pořádnému rozvíŕení mediální scény, nicméně v konečném důsledku ovlivnila hlasování pouze každého 20. voliče (Hajek 2017: 185). Domnívám se, že sociální demokracii spíše pomohla, nebot’ do té doby se jednalo ze strany SPÖ a předsedy Kerna o křečovitou snahu reagovat na razantní nástup svého hlavního soupeře Sebastiana Kurze. Kern v závěru kampaně působil velmi koncentrovaně a uvolněně zároveň, pravděpodobně v duchu hesla „nemám co ztratit“; připomněl, že sleduje dlouhodobé cíle, nebot' chce zůstat $\mathrm{v}$ politice 10 let a za tu dobu výrazně snížit nezaměstnanost, přispět $\mathrm{k}$ faktickému zrovnoprávnění žen a pokračovat v kombinaci hospodářské prosperity a sociální soudržnosti, po vzoru svého slavnějš́ího předchůdce Bruna Kreiského. $\mathrm{K}$ tomu přidal varování před „sociálními experimenty“, pokud by došlo k vytvoření vládní koalice lidovců a Svobodných. Sociální demokracie se tak s úspěchem stylizovala do pozice státoprávního subjektu s jasnou vizí „hráze“ bránící posunu Rakouska doprava (SPÖ 2017g, i). Strana našla pro poslední dva týdny volební kampaně kombinaci témat umožňujících mobilizovat své př́znivce a oslovit voliče především Zelených, zejména ve městech a městských aglomeracích. $\mathrm{V}$ konečném důsledku tak SPÖ odvrátila po zveřejnění Silbersteinovy aféry reálnou hrozbu historicky nejnižší podpory elektorátu ve volbách do parlamentu v rakouských dějinách.

\section{Výsledky parlamentních voleb}

Volby do Národní rady, pro které se využívá poměrného volebního systému kandidátních listin s možností udělení preferenčního hlasu, přičemž pro vstup do rakouského parlamentu je potřebné na spolkové úrovni překročit $4 \%$ uzavírací klauzuli, přinesly několik zásadních událostí. Teprve potřetí v rakouské historii nedokázal úřadující spolkový kancléř udržet první místo (v roce 1970 takto dopadl Josef Klaus a v roce 2006 Wolfgang Schüssel). Poprvé od roku 2002 zvítězili lidovci, následováni sociální demokracií a Svobodnými. Do Národní rady proniklo ještě Nové Rakousko a Kandidátka Petera Pilze, naopak 
po 31 letech pozbyli parlamentní relevanci na spolkové úrovni Zelení. Výsledky voleb v celostátním měrítku ve srovnání s volbami do Národní rady v roce 2013 shrnují Tabulky 1 a 2.

Tabulka 1: Oficiální výsledky parlamentních voleb 2017 - počet hlasů

\begin{tabular}{|c|c|c|c|c|c|c|c|}
\hline $\begin{array}{c}\text { Název strany } \\
\text { (česky) }\end{array}$ & $\begin{array}{c}\text { Zkratka } \\
\text { (dle názvu } \\
\text { v němčině) }\end{array}$ & $\begin{array}{c}\text { Počet } \\
\text { získaných } \\
\text { hlasů } 2017\end{array}$ & $\begin{array}{c}\text { Výsledek } \\
2017 \\
(\mathrm{v} \%)\end{array}$ & $\begin{array}{c}\text { Počet } \\
\text { získaných } \\
\text { hlasů } 2013\end{array}$ & $\begin{array}{c}\text { Výsledek } \\
2013 \\
(\mathrm{v} \%)\end{array}$ & $\begin{array}{c}\text { Rozdíl } \\
\text { počtu } \\
\text { hlasů } \\
2013-17\end{array}$ & $\begin{array}{c}\text { Rozdíl } \\
\text { výsledku } \\
\mathrm{v} \%\end{array}$ \\
\hline $\begin{array}{c}\text { Rakouská lidová } \\
\text { strana }\end{array}$ & ÖVP & 1595526 & $31,5 \%$ & 1125876 & $24,0 \%$ & 469650 & $7,5 \%$ \\
\hline $\begin{array}{c}\text { Sociálnědemokr } \\
\text { atická strana } \\
\text { Rakouska }\end{array}$ & SPÖ & 1361746 & $26,9 \%$ & 1258605 & $26,8 \%$ & 103141 & $0,1 \%$ \\
\hline $\begin{array}{c}\text { Svobodná strana } \\
\text { Rakouska }\end{array}$ & FPÖ & 1316442 & $26,0 \%$ & 962313 & $20,5 \%$ & 354129 & $5,5 \%$ \\
\hline NEOS & NEOS & 268518 & $5,3 \%$ & 232946 & $5,0 \%$ & 35572 & $0,3 \%$ \\
\hline $\begin{array}{c}\text { Kandidátka } \\
\text { Petera Pilze }\end{array}$ & PILZ & 223544 & $4,4 \%$ & - & - & - & - \\
\hline $\begin{array}{c}\text { Zelení - Zelená } \\
\text { alternativa }\end{array}$ & Grüne & 192638 & $3,8 \%$ & 582657 & $12,4 \%$ & -390019 & $-8,6 \%$ \\
\hline
\end{tabular}

Zdroj: BMI (2017)

Tabulka 2: Oficiální výsledky parlamentních voleb 2017 - počet mandátů

\begin{tabular}{|c|c|c|c|}
\hline $\begin{array}{c}\text { Kandidující } \\
\text { subjekt }\end{array}$ & $\begin{array}{c}\text { Počet získaných } \\
\text { mandátů 2017 }\end{array}$ & $\begin{array}{c}\text { Počet získaných } \\
\text { mandátů 2013 }\end{array}$ & Rozdíl 2013-17 \\
\hline ÖVP & 62 & 47 & 15 \\
\hline SPÖ & 52 & 52 & 0 \\
\hline FPÖ & 51 & 40 & 11 \\
\hline NEOS & 10 & 9 & 8 \\
\hline PILZ & 8 & - & -24 \\
\hline Grüne & 0 & 24 & 1 \\
\hline
\end{tabular}

Zdroj: BMI (2017)

Vítězní lidovci těžili především ze schopností svého lídra, který představoval hlavní motiv pro voliče, proč tentokrát podpořili ÖVP (Hajek 2017: 183; SORA 2017: 9-10; Plasser a Sommer 2018: 97, 100). Sebastian Kurz působil dynamicky, prritom mu ale nechybělo značné sebevědomí a schopnost 
motivovat lidi kolem sebe, včetně nižších organizačních struktur strany. Kurz disponuje také značnými rétorickými schopnostmi a velmi dobře zvládá komunikaci s voliči. Během četných televizních diskusí dokázal nastolovat témata, která jeho strana prosazovala. Často si přitom pomáhal zdánlivě nevinnou otázkou: „Smím krátce říct ještě jednu větu?“ Druhá přičina spočívá ve zdařilé změně stranické image, která vzbudila ve voličích dojem, že opravdu vzniká hnutí s cílem vybudovat něco nového a pozitivního. Třetí důvod představuje výběr předvolebních témat, která rakouská společnost považuje za důležitá. Kurz od počátku upřednostnil problematiku migrace, azylovou politiku a integraci cizinců do většinové rakouské společnosti, k čemuž přidal slib snížení daňové zátěže i kriminality. Klasická sociálnědemokratická témata, jako např́klad reforma zdravotnictví a penzijního systému, hrála v loňských volbách méně důležitou roli (SORA 2017: 11; Plasser a Sommer 2018: 86-94). Čtvrtou př́činou byla profesionálně vedená volební kampaň zaměřená takřka výhradně na Kurze. ÖVP ji odstartovala již květnu, prakticky okamžitě po vyhlášení předčasných voleb. Za prozíravý strategický tah lze považovat postupnou prezentaci kandidátů na volitelných místech, stejně jako volebního programu, která vyvolal; a pozornost veřejnosti a médií, ale nijak zvlášt’ neobtěžovala, takže voliči měli možnost „odpočinku“.

Diferencovanější a méně personalizované byly motivy $\mathrm{k}$ podpoře sociální demokracie. Nejvíce voliče oslovil program a hodnoty strany spolu se sociální image SPÖ a očekávaná kompetence v sociálně-politických otázkách (Hajek 2017: 183; SORA 2017: 10). Dalším podstatným motivem byla snaha zabránit koalici FPÖ a ÖVP, především u voličů, kteří v minulosti podpořili jiné politické subjekty (Plasser a Sommer 2018: 101). Sociální demokracie získala tradičně nejvyšší př́zeň ve městech a městských aglomeracích mezi voliči nad 50 let (Hajek 2017: 185).

Překvapující výsledky přinesla analýza volebních motivů u Svobodné strany Rakouska. Restriktivní migrační a azylová politika představovala pro třetinu voličů hlavní důvod, proč podpořili FPÖ (Plasser a Sommer 2018: 101). Solidní odezvu mezi nimi vyvolala snaha strany stylizovat se do pozice "hybatele“ změn pro Rakousko a předem deklarovaná př́pravenost představitelů FPÖ převzít vládní odpovědnost a zabránit tím pokračování vlády velké koalice. Lídr Svobodných Heinz-Christian Strache představoval až čtvrtý nejčastější důvod podpory FPÖ (Hajek 2017: 184; SORA 2017: 9; Plasser a Sommer 2018: 102). Naopak nepřekvapil socioprofesní, genderový a věkový profil voličủ FPÖ. Svobodní oslovili především pracující muže dělnických profesí nastupující a střední generace s nižším vzděláním (SORA 2017: 4-5; Hajek 2017: 185).

Liberálové obsadili čtvrté místo, ale jejich konečný zisk zdaleka neodpovídal proklamovaným ambicím dosáhnout dvouciferného výsledku. Hlavním motivem $\mathrm{k}$ podpoře NEOS byl jejich program a liberálního hodnoty, které se snaží prosazovat, konkrétně návrhy na reformu vzdělávací soustavy a zlepšení 
hospodářské výkonnosti Rakouska. Lídr NEOS Matthias Stolz představoval důležitou pohnutku pro voliče, kteří podpořili NEOS již v roce 2013. Rovněž u prŕviženců liberálů byla důležitým motivem strategická volba s ohledem na budoucí koalici, zamýšleli zabránit pokračování spolupráce sociální demokracie a lidovců (Hajek 2017: 184; Plasser a Sommer 2018: 102).

Parlamentní volby potvrdily trend patrný od první účasti NEOS ve volbách v roce 2013, tedy že strana má vyšší podporu ve větších městech a městských aglomeracích než v menších obcích. Nejlépe dopadla ve spolkové zemi Vorarlbersko, kde se o důvěru voličů ucházel Matthias Strolz. Nadprůměrného rezultátu dosáhli liberálové rovněž ve Vídni, k čemuž přispěla komunálně známá Beate Meinl-Reisingerová profilující se kritikou vládnutí dlouhodobě etablovaných stran.

Poslední pronikla do Národní rady Kandidátka Petera Pilze. Strana profitovala z dlouholeté parlamentní práce svého zakladatele a lídra a z úspěšné image kontrolního a protikorupčního subjektu (Hajek 2017: 184; Plasser a Sommer 2018: 102). PILZ oslovil především bývalé voliče Zelených, sociální demokracie a někdejší nevoliče (SORA 2017: 2-3). Čtyřprocentní hranici potřebnou ke vstupu do parlamentu překonal pouze ve Vídni, nicméně 7,51\% zde získaných hlasů mu $\mathrm{v}$ součtu s podporou $\mathrm{v}$ ostatních spolkových zemí $\mathrm{k}$ dosažení parlamentní relevance stačilo. PILZ se prosadil především ve vídeňských obvodech, kde v nedávné minulosti „bodovali“ Zelení (Mariahilf, Neubau, Josefstadt). Do budoucna však může být problémem nedostatečný personál a zcela absentující organizační struktura na zemské a obecní úrovni.

Pro Zelené skončily volby do Národní rady doslova katastrofou, když po 31 letech pozbyli parlamentní relevance na spolkové úrovni. O tomto výsledku rozhodlo hned několik okolností najednou. Vyloučení mládežnické organizace a náhlý odchod spolkové mluvčí Evy Glawischniggové i Petera Pilze vytvořily dojem vnitřně nejednotné strany, která se zabývá spíše svými vlastními problémy, než aby naslouchala voličům. Zelení se ve volební kampani snažili zaujmout tradičními tématy, ale ochranu životního prostředí, lidská práva a práva menšin nepovažovali voliči za zásadní společenské otázky. Nevýhodou byla nominace zkušené Ulrike Lunacekové, jež působila ve srovnání s ostatními stranickými lídry nevýrazně (Hajek 2017: 184; Plescia a Aichholzer 2018; Plasser a Sommer 2018: 102).

Podle rakouských politologů Fritze Plassera a Franze Sommera 43 \% voličů, kteří v roce 2013 dali důvěru Zeleným, podpořilo o čtyři roky později sociální demokracii. Jednalo se zejména o strategickou volbu s cílem zabránit vytvoření koalice ÖVP a FPÖ, přičemž z hlediska strany zásadní počet $z$ nich se pro SPÖ rozhodl v posledních dvou týdnech volební kampaně. Dalších 21 \% někdejších voličů Zelených projevilo v ř́jnu 2017 důvěru Kandidátce Petera Pilze, 14 \% tentokrát neprrišlo $\mathrm{k}$ volbám, $12 \%$ přešlo $\mathrm{k}$ lidovcům a $10 \%$ podpořilo NEOS (Plasser a Sommer 2018: 32, 85). V reakci na neúspěch odstoupila Ingrid 
Felipeová z vedení strany a Ulrike Lunaceková se vzdala mandátu v Evropském parlamentu. Funkci spolkového mluvčího Zelených převzal zkušený Werner Kogler (Mayr et al. 2017; Gigler 2017). Žádné straně se v Rakousku dosud nepodařilo po ztrátě mandátů $\mathrm{v}$ Národní radě $\mathrm{v}$ pozdějším období znovu nabýt parlamentní relevance. ${ }^{24}$ Zelení v tomto ohledu mohou přepsat historii, nebot' mají oproti neúspěšným předchůdcům hned několik výhod. Za déle než tři dekády se jim podařilo vybudovat stabilní organizační strukturu ve všech oblastech Rakouska. ${ }^{25}$ Zelení rovněž vykazují dlouhodobě stabilní zakotvení na zemské a komunální úrovni. Strana má zastoupení ve všech zemských sněmech kromě Korutan a podílí se na exekutivě ve třech z devíti spolkových zemí; disponuje také třemi zákonodárci v Evropském parlamentu. ${ }^{26}$

Detailnější pohled do výsledků v jednotlivých spolkových zemích (viz Tabulku 3) prozrazuje, že ÖVP a FPÖ posílily ve všech částech Rakouska, zatímco Zelení zaznamenali podstatné ztráty. Vítězná ÖVP potvrdila silné zemské zakotvení, když obsadila první místo v Dolním a Horním Rakousku, Salcbursku, Štýrsku, Tyrolsku a Vorarlbersku, tedy ve všech spolkových zemích, kde v současné době strana zastává funkci zemského hejtmana.

\section{Tabulka 3: Výsledky parlamentních voleb podle spolkových zemí}

\section{Burgenland}

\begin{tabular}{|c|c|c|c|c|c|c|c|c|c|}
\hline $\begin{array}{c}\text { Kandi- } \\
\text { dující } \\
\text { subjekt }\end{array}$ & $\begin{array}{c}\text { Počet } \\
\text { hlasů } \\
2017\end{array}$ & $\begin{array}{c}\text { Počet } \\
\text { hlasů } \\
2017 \\
(\%)\end{array}$ & $\begin{array}{c}\text { Počet } \\
\text { hlasů } \\
2013\end{array}$ & $\begin{array}{c}\text { Počet } \\
\text { hlasů } \\
2013 \\
(\%)\end{array}$ & $\begin{array}{c}\text { Rozdíl } \\
\text { v počtu } \\
\text { hlasů } \\
2013-17\end{array}$ & $\begin{array}{c}\text { Rozdíl } \\
\text { ve } \\
\text { výsledku } \\
(\%)\end{array}$ & $\begin{array}{c}\text { Počet } \\
\text { získaných } \\
\text { mandátů } \\
2017\end{array}$ & $\begin{array}{c}\text { Počet } \\
\text { získaných } \\
\text { mandátů } \\
2013\end{array}$ & $\begin{array}{c}\text { Rozdíl } \\
\text { v počtu } \\
\text { získaných } \\
\text { mandátů }\end{array}$ \\
\hline SPÖ & 64070 & $32,9 \%$ & 70222 & $37,3 \%$ & -6152 & $-4,4 \%$ & 2 & 2 & 0 \\
\hline ÖVP & 63858 & $32,8 \%$ & 50426 & $26,8 \%$ & 13432 & $6,0 \%$ & 2 & 1 & 1 \\
\hline FPÖ & 49127 & $25,2 \%$ & 32705 & $17,4 \%$ & 16422 & $7,8 \%$ & 1 & 1 & 0 \\
\hline NEOS & 5603 & $2,9 \%$ & 5327 & $2,8 \%$ & 276 & $0,1 \%$ & 0 & 0 & 0 \\
\hline PILZ & 5529 & $2,8 \%$ & - & - & - & - & 0 & - & 0 \\
\hline Zelení & 3932 & $2,0 \%$ & 12708 & $6,8 \%$ & -8786 & $-4,8 \%$ & 0 & 0 & 0 \\
\hline
\end{tabular}

${ }^{24} \mathrm{~V}$ roce 1959 ztratili parlamentní relevanci komunisté. Liberální fórum vzniknuvší odštěpením ze FPÖ v roce 1993 pozbylo křesla v Národní radě o šest let později, aby v roce 2013 uzavřelo volební spolek s NEOS. O rok později došlo k definitivnímu sloučení obou stran a Liberální fórum jako samostatný subjekt přestalo existovat. Svaz pro budoucnost Rakouska působil v Národní radě osm let (2005-2013). Osud Týmu Stronach již byl zmíněn.

${ }^{25}$ K organizační struktuře Zelených srov. Dachs (2006: 392-395).

${ }^{26}$ Stav k 9. 1. 2019. 
Vídeň

\begin{tabular}{|c|c|c|c|c|c|c|c|c|c|}
\hline $\begin{array}{c}\text { Kandi- } \\
\text { dující } \\
\text { subjekt }\end{array}$ & $\begin{array}{c}\text { Počet } \\
\text { hlasů }\end{array}$ & $\begin{array}{c}\text { Počet } \\
\text { hlasů } \\
2017 \\
(\%)\end{array}$ & $\begin{array}{c}\text { Počet } \\
\text { hlasů } \\
2013\end{array}$ & $\begin{array}{c}\text { Počet } \\
\text { hlasů } \\
2013 \\
(\%)\end{array}$ & $\begin{array}{c}\text { Rozdíl } \\
\text { v počtu } \\
\text { hlasů } \\
2013-17\end{array}$ & $\begin{array}{c}\text { Rozdíl } \\
\text { ve } \\
\text { výsledku } \\
(\%)\end{array}$ & $\begin{array}{c}\text { Počet } \\
\text { získaných } \\
\text { mandátů } \\
2017\end{array}$ & $\begin{array}{c}\text { Počet } \\
\text { získaných } \\
\text { mandátů } \\
2013\end{array}$ & $\begin{array}{c}\text { Rozdíl } \\
\text { v počtu } \\
\text { získaných } \\
\text { mandátů }\end{array}$ \\
\hline SPÖ & 300664 & $34,5 \%$ & 251623 & $31,6 \%$ & 49041 & $2,9 \%$ & 11 & 10 & 1 \\
\hline ÖVP & 188273 & $21,6 \%$ & 115316 & $14,5 \%$ & 72957 & $7,1 \%$ & 7 & 4 & 3 \\
\hline FPÖ & 186088 & $21,3 \%$ & 163501 & $20,6 \%$ & 22587 & $0,7 \%$ & 7 & 6 & 1 \\
\hline PILZ & 65498 & $7,5 \%$ & - & - & - & - & 2 & - & 2 \\
\hline NEOS & 56323 & $6,5 \%$ & 60812 & $7,6 \%$ & -4489 & $-1,2 \%$ & 2 & 2 & 0 \\
\hline Zelení & 51398 & $5,9 \%$ & 130142 & $16,4 \%$ & -79094 & $-10,5 \%$ & 0 & 5 & -5 \\
\hline
\end{tabular}

\section{Korutany}

\begin{tabular}{|c|c|c|c|c|c|c|c|c|c|}
\hline $\begin{array}{c}\text { Kandi- } \\
\text { dující } \\
\text { subjekt }\end{array}$ & $\begin{array}{c}\text { Počet } \\
\text { hlasů }\end{array}$ & $\begin{array}{c}\text { Počet } \\
\text { hlasů } \\
2017 \\
(\%)\end{array}$ & $\begin{array}{c}\text { Počet } \\
\text { hlasů } \\
2013\end{array}$ & $\begin{array}{c}\text { Počet } \\
\text { hlasů } \\
2013 \\
(\%)\end{array}$ & $\begin{array}{c}\text { Rozdíl } \\
\text { v počtu } \\
\text { hlasů } \\
2013-17\end{array}$ & $\begin{array}{c}\text { Rozdíl } \\
\text { ve } \\
\text { výsledku } \\
(\%)\end{array}$ & $\begin{array}{c}\text { Počet } \\
\text { získaných } \\
\text { mandátů } \\
2017\end{array}$ & $\begin{array}{c}\text { Počet } \\
\text { získaných } \\
\text { mandátu் } \\
2013\end{array}$ & $\begin{array}{c}\text { Rozdíl } \\
\text { v počtu } \\
\text { získaných } \\
\text { mandátů }\end{array}$ \\
\hline FPÖ & 108215 & $31,8 \%$ & 56513 & $17,9 \%$ & 51702 & $13,9 \%$ & 4 & 2 & 2 \\
\hline SPÖ & 99923 & $29,3 \%$ & 102278 & $32,4 \%$ & -2355 & $-3,1 \%$ & 3 & 4 & -1 \\
\hline ÖVP & 91458 & $26,8 \%$ & 48140 & $15,2 \%$ & 43318 & $11,6 \%$ & 3 & 1 & 2 \\
\hline NEOS & 14692 & $4,3 \%$ & 11711 & $3,7 \%$ & 2981 & $0,6 \%$ & 0 & 0 & 0 \\
\hline PILZ & 12298 & $3,6 \%$ & - & - & - & - & 0 & - & 0 \\
\hline Zelení & 8249 & $2,4 \%$ & 37304 & $11,8 \%$ & -29055 & $-9,4 \%$ & 0 & 1 & -1 \\
\hline
\end{tabular}

\section{Dolní Rakousko}

\begin{tabular}{|c|c|c|c|c|c|c|c|c|c|}
\hline $\begin{array}{c}\text { Kandi- } \\
\text { dující } \\
\text { subjekt }\end{array}$ & $\begin{array}{c}\text { Počet } \\
\text { hlasů } \\
2017\end{array}$ & $\begin{array}{c}\text { Počet } \\
\text { hlasů } \\
2017 \\
(\%)\end{array}$ & $\begin{array}{c}\text { Počet } \\
\text { hlasů } \\
2013\end{array}$ & $\begin{array}{c}\text { Počet } \\
\text { hlasů } \\
2013 \\
(\%)\end{array}$ & $\begin{array}{c}\text { Rozdíl } \\
\text { v počtu } \\
\text { hlasů } \\
2013-17\end{array}$ & $\begin{array}{c}\text { Rozdíl } \\
\text { ve } \\
\text { výsledku } \\
(\%)\end{array}$ & $\begin{array}{c}\text { Počet } \\
\text { získaných } \\
\text { mandátů } \\
2017\end{array}$ & $\begin{array}{c}\text { Počet } \\
\text { získaných } \\
\text { mandátů } \\
2013\end{array}$ & $\begin{array}{c}\text { Rozdíl } \\
\text { v počtu } \\
\text { získaných } \\
\text { mandátů }\end{array}$ \\
\hline ÖVP & 384279 & $35,6 \%$ & 310345 & $30,6 \%$ & 73934 & $5,0 \%$ & 13 & 11 & 2 \\
\hline FPÖ & 280011 & $25,9 \%$ & 190601 & $18,8 \%$ & 89410 & $7,1 \%$ & 9 & 6 & 3 \\
\hline SPÖ & 267348 & $24,8 \%$ & 279988 & $27,6 \%$ & -12640 & $-2,8 \%$ & 9 & 10 & -1 \\
\hline NEOS & 51815 & $4,8 \%$ & 45285 & $4,5 \%$ & 6530 & $0,3 \%$ & 1 & 1 & 0 \\
\hline PILZ & 44767 & $4,1 \%$ & - & - & - & - & 1 & - & 1 \\
\hline Zelení & 29619 & $2,7 \%$ & 97487 & $9,6 \%$ & -67868 & $-6,9 \%$ & 0 & 3 & -3 \\
\hline
\end{tabular}




\section{Horní Rakousko}

\begin{tabular}{|c|c|c|c|c|c|c|c|c|c|}
\hline $\begin{array}{c}\text { Kandi- } \\
\text { dující } \\
\text { subjekt }\end{array}$ & $\begin{array}{c}\text { Počet } \\
\text { hlasů }\end{array}$ & $\begin{array}{c}\text { Počet } \\
\text { hlasů } \\
2017 \\
(\%)\end{array}$ & $\begin{array}{c}\text { Počet } \\
\text { hlasů } \\
2013\end{array}$ & $\begin{array}{c}\text { Počet } \\
\text { hlasů } \\
2013 \\
(\%)\end{array}$ & $\begin{array}{c}\text { Rozdíl } \\
\text { v počtu } \\
\text { hlasů } \\
2013-17\end{array}$ & $\begin{array}{c}\text { Rozdíl } \\
\text { ve } \\
\text { výsledku } \\
(\%)\end{array}$ & $\begin{array}{c}\text { Počet } \\
\text { získaných } \\
\text { mandátů } \\
2017\end{array}$ & $\begin{array}{c}\text { Počet } \\
\text { získaných } \\
\text { mandátů } \\
2013\end{array}$ & $\begin{array}{c}\text { Rozdíl } \\
\text { v počtu } \\
\text { získaných } \\
\text { mandátů }\end{array}$ \\
\hline ÖVP & 280595 & $31,5 \%$ & 212843 & $25,4 \%$ & 67752 & $6,1 \%$ & 10 & 8 & 2 \\
\hline SPÖ & 246201 & $27,6 \%$ & 228293 & $27,2 \%$ & 17908 & $0,4 \%$ & 8 & 8 & 0 \\
\hline FPÖ & 239444 & $26,8 \%$ & 180041 & $21,4 \%$ & 59403 & $5,4 \%$ & 8 & 6 & 2 \\
\hline NEOS & 42556 & $4,8 \%$ & 28604 & $3,4 \%$ & 13952 & $1,4 \%$ & 1 & 1 & 0 \\
\hline Zelení & 32792 & $3,7 \%$ & 102003 & $12,2 \%$ & -69211 & $-8,5 \%$ & 0 & 3 & -3 \\
\hline PILZ & 32772 & $3,7 \%$ & - & - & - & - & 1 & - & 1 \\
\hline
\end{tabular}

\section{Salcbursko}

\begin{tabular}{|c|c|c|c|c|c|c|c|c|c|}
\hline $\begin{array}{c}\text { Kandi- } \\
\text { dující } \\
\text { subjekt }\end{array}$ & $\begin{array}{c}\text { Počet } \\
\text { hlasů } \\
2017\end{array}$ & $\begin{array}{c}\text { Počet } \\
\text { hlasů } \\
2017 \\
(\%)\end{array}$ & $\begin{array}{c}\text { Počet } \\
\text { hlasů } \\
2013\end{array}$ & $\begin{array}{c}\text { Počet } \\
\text { hlasů } \\
2013 \\
(\%)\end{array}$ & $\begin{array}{c}\text { Rozdíl } \\
\text { v počtu } \\
\text { hlasů } \\
2013-17\end{array}$ & $\begin{array}{c}\text { Rozdíl } \\
\text { ve } \\
\text { výsledku } \\
(\%)\end{array}$ & $\begin{array}{c}\text { Počet } \\
\text { získaných } \\
\text { mandátů } \\
2017\end{array}$ & $\begin{array}{c}\text { Počet } \\
\text { získaných } \\
\text { mandátů } \\
2013\end{array}$ & $\begin{array}{c}\text { Rozdíl } \\
\text { v počtu } \\
\text { získaných } \\
\text { mandátů }\end{array}$ \\
\hline ÖVP & 109072 & $37,7 \%$ & 76460 & $26,7 \%$ & 42612 & $11,0 \%$ & 4 & 2 & 2 \\
\hline FPÖ & 77120 & $24,4 \%$ & 60876 & $21,2 \%$ & 16244 & $3,2 \%$ & 2 & 2 & 0 \\
\hline SPÖ & 70191 & $22,2 \%$ & 65950 & $23,0 \%$ & 4241 & $-0,8 \%$ & 2 & 2 & 0 \\
\hline NEOS & 17985 & $5,7 \%$ & 13103 & $4,6 \%$ & 4882 & $1,1 \%$ & 0 & 0 & 0 \\
\hline Zelení & 12714 & $4,0 \%$ & 42389 & $14,8 \%$ & -29675 & $-10,8 \%$ & 0 & 1 & -1 \\
\hline PILZ & 11149 & $3,5 \%$ & - & - & - & - & 0 & - & 0 \\
\hline
\end{tabular}

\section{Štýrsko}

\begin{tabular}{|c|c|c|c|c|c|c|c|c|c|}
\hline $\begin{array}{c}\text { Kandi- } \\
\text { dující } \\
\text { subjekt }\end{array}$ & $\begin{array}{c}\text { Počet } \\
\text { hlasů } \\
2017\end{array}$ & $\begin{array}{c}\text { Počet } \\
\text { hlasů } \\
2017 \\
(\%)\end{array}$ & $\begin{array}{c}\text { Počet } \\
\text { hlasu } \\
2013\end{array}$ & $\begin{array}{c}\text { Počet } \\
\text { hlasů } \\
2013 \\
(\%)\end{array}$ & $\begin{array}{c}\text { Rozdíl } \\
\text { v počtu } \\
\text { hlasů } \\
2013-17\end{array}$ & $\begin{array}{c}\text { Rozdíl } \\
\text { ve } \\
\text { výsledku } \\
(\%)\end{array}$ & $\begin{array}{c}\text { Počet } \\
\text { získaných } \\
\text { mandátů } \\
2017\end{array}$ & $\begin{array}{c}\text { Počet } \\
\text { získaných } \\
\text { mandátů } \\
2013\end{array}$ & $\begin{array}{c}\text { Rozdíl } \\
\text { v počtu } \\
\text { získaných } \\
\text { mandátů }\end{array}$ \\
\hline ÖVP & 241917 & $31,5 \%$ & 151438 & $20,9 \%$ & 90479 & $10,6 \%$ & 8 & 5 & 3 \\
\hline FPÖ & 225990 & $29,4 \%$ & 173908 & $24,0 \%$ & 52082 & $5,4 \%$ & 7 & 6 & 1 \\
\hline SPÖ & 192738 & $25,1 \%$ & 172307 & $23,8 \%$ & 20431 & $1,3 \%$ & 6 & 6 & 0 \\
\hline NEOS & 38341 & $5,0 \%$ & 27872 & $3,9 \%$ & 10469 & $1,1 \%$ & 1 & 1 & 0 \\
\hline PILZ & 29980 & $3,9 \%$ & - & - & - & - & 1 & - & 1 \\
\hline Zelení & 21430 & $2,8 \%$ & 76547 & $10,6 \%$ & -55117 & $-7,8 \%$ & 0 & 2 & -2 \\
\hline
\end{tabular}


Tyrolsko

\begin{tabular}{|c|c|c|c|c|c|c|c|c|c|}
\hline $\begin{array}{c}\text { Kandi- } \\
\text { dující } \\
\text { subjekt }\end{array}$ & $\begin{array}{c}\text { Počet } \\
\text { hlasů }\end{array}$ & $\begin{array}{c}\text { Počet } \\
\text { hlasů } \\
2017 \\
(\%)\end{array}$ & $\begin{array}{c}\text { Počet } \\
\text { hlasů } \\
2013\end{array}$ & $\begin{array}{c}\text { Počet } \\
\text { hlasů } \\
2013 \\
(\%)\end{array}$ & $\begin{array}{c}\text { Rozdíl } \\
\text { v počtu } \\
\text { hlasů } \\
2013-17\end{array}$ & $\begin{array}{c}\text { Rozdíl } \\
\text { ve } \\
\text { výsledku } \\
(\%)\end{array}$ & $\begin{array}{c}\text { Počet } \\
\text { získaných } \\
\text { mandátu் } \\
2017\end{array}$ & $\begin{array}{c}\text { Počet } \\
\text { získaných } \\
\text { mandátů } \\
2013\end{array}$ & $\begin{array}{c}\text { Rozdíl } \\
\text { v počtu } \\
\text { získaných } \\
\text { mandátů }\end{array}$ \\
\hline ÖVP & 158092 & $38,4 \%$ & 114754 & $32,3 \%$ & 43338 & $6,1 \%$ & 5 & 4 & 1 \\
\hline FPÖ & 102610 & $24,9 \%$ & 68761 & $19,4 \%$ & 33849 & $5,6 \%$ & 3 & 2 & 1 \\
\hline SPÖ & 85650 & $20,8 \%$ & 64923 & $18,3 \%$ & 20727 & $2,5 \%$ & 3 & 2 & 1 \\
\hline NEOS & 23537 & $5,7 \%$ & 17344 & $4,9 \%$ & 6193 & $0,8 \%$ & 0 & 0 & 0 \\
\hline Zelení & 18367 & $4,5 \%$ & 53910 & $15,2 \%$ & -35543 & $-10,7 \%$ & 0 & 2 & -2 \\
\hline PILZ & 15746 & $3,8 \%$ & - & - & - & - & 0 & - & 0 \\
\hline
\end{tabular}

\section{Vorarlbersko}

\begin{tabular}{|c|c|c|c|c|c|c|c|c|c|}
\hline $\begin{array}{c}\text { Kandi- } \\
\text { dující } \\
\text { subjekt }\end{array}$ & $\begin{array}{c}\text { Počet } \\
\text { hlasů }\end{array}$ & $\begin{array}{c}\text { Počet } \\
\text { hlasů } \\
2017 \\
(\%)\end{array}$ & $\begin{array}{c}\text { Počet } \\
\text { hlasů } \\
2013\end{array}$ & $\begin{array}{c}\text { Počet } \\
\text { hlasů } \\
2013 \\
(\%)\end{array}$ & $\begin{array}{c}\text { Rozdíl } \\
\text { v počtu } \\
\text { hlasů } \\
2013-17\end{array}$ & $\begin{array}{c}\text { Rozdíl } \\
\text { ve } \\
\text { výsledku } \\
(\%)\end{array}$ & $\begin{array}{c}\text { Počet } \\
\text { získaných } \\
\text { mandátů } \\
2017\end{array}$ & $\begin{array}{c}\text { Počet } \\
\text { získaných } \\
\text { mandátů } \\
2013\end{array}$ & $\begin{array}{c}\text { Rozdíl } \\
\text { v počtu } \\
\text { získaných } \\
\text { mandátů }\end{array}$ \\
\hline ÖVP & 67982 & $34,7 \%$ & 46154 & $26,3 \%$ & 21828 & $8,4 \%$ & 2 & 2 & 0 \\
\hline FPÖ & 47837 & $24,4 \%$ & 35407 & $20,2 \%$ & 12430 & $4,2 \%$ & 1 & 1 & 0 \\
\hline SPÖ & 34961 & $17,8 \%$ & 23021 & $13,1 \%$ & 11940 & $4,7 \%$ & 1 & 1 & 0 \\
\hline NEOS & 17666 & $9,0 \%$ & 22888 & $13,1 \%$ & -5222 & $-4,0 \%$ & 0 & 1 & -1 \\
\hline Zelení & 14137 & $7,2 \%$ & 29807 & $17,0 \%$ & -15670 & $-9,8 \%$ & 0 & 1 & -1 \\
\hline PILZ & 5804 & $3,0 \%$ & - & - & - & - & 0 & - & 0 \\
\hline
\end{tabular}

Zdroj: BMI (2017)

Zajímavé vyústění nabídly ostatní části Rakouska, kde první místo získaly jiné politické subjekty. V Burgenlandu na sebe narazili v pozici lídrů zemských kandidátek ministr obrany Hans-Peter Doskozil (SPÖ) a Norbert Hofer (FPÖ). Oba mohou za určitých okolností zaujmout v budoucnu ve svých stranách nejvyšší funkci. SPÖ mírně ztratila ve městech, přesto dokázala obhájit první pozici. Druhé místo obsadili lidovci, třetí skončili s historicky nejlepším výsledkem Svobodní.

Ve Vídni poslala SPÖ do konfrontace prŕmo spolkového kancléře Christiana Kerna. Popularita úřadujícího kancléŕe a strategická volba někdejších voličů Zelených s ohledem na povolební vyjednávání zabezpečila mírný nárůst hlasů ve srovnání s rokem 2013. Do výsledků voleb se tak neprojevila tehdy probíhající debata o nástupnictví po populárním vídeňském starostovi Michaelu Häuplovi. Druzí Svobodní dosáhli vůbec nejhoršího výsledku ze všech spolkových zemí, a to 
i navzdory tomu, že zde kandidoval Heinz Christian Strache. To by naznačovalo, že pro FPÖ už není zdaleka tak klíčovou osobou, jako tomu bylo v minulosti.

V Korutanech navázali Svobodní na parlamentní volby v roce 1999, kdy zde pod vedením Jörga Haidera dokázali získat nejvyšší počet hlasů. FPÖ přtom dokázala oslovit většinu někdejších voliču Týmu Stronach a Svazu pro budoucnost Rakouska (v roce 2013 obdrželi dohromady 17,7 \% odevzdaných hlasů).

\section{Vytvářrení vládní koalice}

Spolkový prezident Alexander Van der Bellen pověril 19. ř́ijna podle rakouských zvyklostí vítěze voleb Sebastiana Kurze sestavením nové spolkové vlády. Předseda lidovců ještě před započetím oficiálních koaličních rozhovorů absolvoval neformální setkání se zástupci všech parlamentních stran. Rozdělení mandátů na základě výsledků voleb zpo̊sobilo, že z koaličních vyjednávání vypadli NEOS a Kandidátka Petera Pilze. Varianty vládní spolupráce se proto zúžily na tři možnosti. Bezprostředně po volbách se jako nejpravděpodobnější jevilo obnovení koaličního modelu z let 2000-2005, tedy spolupráce lidovců a Svobodných, kterou si rovněž práli voliči obou stran (APA, Der Standard, 17. 10. 2017). ${ }^{27}$ Pro FPÖ přinášela rizika $v$ podobě pozice, ,juniorního partnera“. Jak již bylo řečeno, ÖVP se v některých otázkách velmi príblízila stanoviskám FPÖ. V takovém př́padě je pro slabší vládní stranu obtížnější získat u veřejnosti srozumitelný a jasný tematický profil.

Druhá možnost by znamenala pokračování velké koalice. Hned první povolební schůzka mezi Kernem a Kurzem ukázala, že o tuto spolupráci nemá zájem ani jedna ze zainteresovaných stran. Debata trvala pouhých 45 minut. Kern poté novinářům sdělil, že se SPÖ připravuje působení v opozici (Neuwirth 2017b). Třetí varianta v podobě kooperace SPÖ a FPÖ by byla umožňovala s ohledem na volební výsledky kooperaci na bázi rovného s rovným. Uvedený model koaliční spolupráce narazil na odpor především u sociální demokracie. Např́ílad vlivný Michael Häupl upozornil na hrozící stranický rozkol, souhlasila-li by SPÖ s vládou za účasti FPÖ (Gebhart 2017).

Sebastian Kurz podle očekávání zahájil 25. října 2017 rozhovory se Svobodnými. Předseda ÖVP prítom slíbil vznik stabilní vlády do Vánoc a zároveň veřejnost ujistil, že se bude jednat o proevropský kabinet, který v zemi provede nezbytné reformy, např́ílad snížení daní. Rozhovory o podobě nové koalice probíhaly ve 25 vyjednávacích skupinách. O podrobnostech jednání pronikly na veřejnost, kromě vyjádření pro tisk, jednou týdně pouze kusé informace. Nejvýznamnější byly dvě ř́dící skupiny složené na straně ÖVP vedle Sebastiana Kurze z generální sekretárky Elisabeth Köstingerové, generálního sekretáře Stefana Steinera, šéfa vídeňské organizace Gernota Blümela a zástupkyně

${ }^{27}$ Identickou preferenci vyslovili voliči obou stran ještě před volbami (Lindorfer 2017). 
předsedy strany Bettiny Glatzové-Kremsnerové. Za FPÖ měli hlavní slovo Heinz Christian Strache, Norbert Hofer, generální sekretář Herbert Kickl, předseda parlamentního klubu Svobodných Norbert Nemeth a dlouholetá poslankyně Anneliese Kitzmüllerová (APA, Wiener Zeitung, 25. 10. 2017).

Během prvního měsíce vyjednávání sladily obě strany řadu důležitých otázek. Expertní skupiny se domluvily na restrikci azylové a migrační politiky i posílení bezpečnostních složek. Shoda panovala rovněž kolem přijetí tzv. bezpečnostního balíčku pro potírání terorismu a efektivnější kontroly hranic, stejně jako omezení Mindestsicherung, zejména pro azylanty. V oblasti školství přpravovali lidovci a Svobodní rozširirení digitalizace a zavedení povinného druhého roku v mateřské školce, $\mathrm{v}$ př́padě individuálních potřeb dítěte např́klad s ohledem na nedostatečné znalosti němčiny. Daňové úlevy u právnických a fyzických osob měly být jedním $\mathrm{z}$ impulsů $\mathrm{k}$ rozvoji rakouského hospodářství. Předmětem dalších diskusí bylo výrazné snížení počtu společností poskytujících sociální pojištění, odstranění povinného členství v profesních komorách, všeobecný zákaz kouření $\mathrm{v}$ gastronomii i posílení instrumentů prímé demokracie (Mittelstaedt, Weissensteiner a Oswald 2017; Redaktion, Kurier 27. 11. 2017; Prior 2017b; John 2017).

Koaliční vyjednávání ukončily ÖVP a FPÖ 15. prosince. O tři dny později následovalo jmenování nové vlády prezidentem Alexandrem Van der Bellenem. Při prvním pohledu na složení rakouského kabinetu mnohé pozorovatele překvapilo přenechání několika klíčových postů Svobodným. Za ministerstvo vnitra odpovídá jeden z blízkých spolupracovníků vicekanclére Heinze-Christiana Stracheho Herbert Kickl, jenž začínal svoji kariéru psaním projevio pro Jörga Haidera. Neúspěšný prezidentský kandidát FPÖ Norbert Hofer obdržel ministerstvo dopravy. Prestižní resort zahraničí vede expertka na Blízký východ, nestranička za Svobodné Karin Kneisslová, rezort obrany převzal vůči Evropské unii velmi kritický štýrský regionální politik Mario Kunasek. Svěřením důležitých ministerstev chtěli lidovci pravděpodobně otestovat koaličního partnera, zda již dostatečně vyzrál pro převzetí vládní odpovědnosti. Před lety totiž vládní angažmá FPÖ vedlo ke značným vnitřním rozporům a faktickému rozštěpení strany.

Stojí za připomenutí, že když se v roce 2000 domluvily stejné subjekty na společné koalici, způsobilo to na mezinárodní scéně vlnu nevole. Evropská unie s poukazem na údajné ohrožení základních demokratických hodnot vyhlásila vůči alpské republice „sankce“, které zredukovaly vzájemné styky na nezbytné minimum. Unii vadila především proticizinecká rétorika Svobodných. Dnes však FPÖ není pokládána za tolik nebezpečnou. Aby kanclér Kurz rozptýlil přetrvávající obavy, navštívil 19. prosince krátce Brusel, a to ještě před prezentací programového prohlášení vlády v Národní radě. Vedoucí představitele Evropské unie - předsedu Evropské komise Jeana-Claude Junckera, předsedu Evropské rady Donalda Tuska a predsedu Evropského parlamentu Antonia Tajaniho ubezpečil o proevropské orientaci nového rakouského kabinetu (Steiner-Gashi 2017; Mayer 2017a; Mayer 2017b). 
Vládní program s názvem „Společně pro naše Rakousko“ avizuje pro alpskou republiku řadu změn a obsahuje několik ambiciózních projektů. Zahrnuje zpř́snění azylové a migrační politiky, změny v sociálním systému (reforma Mindestsicherung, snížení počtu společností pro sociální pojištěnî), nebo daňové úlevy pro fyzické a právnické osoby. Vedle snížení daní má rodiny podpořit zavedení tzv. rodinného bonusu. Veřejná správa má být zefektivněna a více digitalizována, i když př́slušné pasáže jsou formulovány velmi obecně. Vzhledem k př́edvolebním slibům překvapí ustanovení týkající se rozšíření nástrojů přímé demokracie. Změny se týkají zejména lidové iniciativy (Volksbegehren). ${ }^{28}$ Pokud se pod petici podepíše $900000^{29}$ oprávněných voličủ a Národní rada v průběhu jednoho roku nepřijme odpovídající legislativní normu, má být požadavek lidové iniciativy předložen v lidovém hlasování (Volksabstimmung) (Regierungsprogramm 2017).

Nová vláda vzbudila v obyvatelích Rakouska značná očekávání: 42 \% Rakušanů ji príjalo s kladnými pocity, $23 \%$ se smíšenými, $19 \%$ ji posuzovalo spíše negativně a 13 \% odmítalo koalici explicitně (Plasser a Sommer 2018: 150). Nejvíce veřejnost oceňovala záměr exekutivy zpřísnit trestní sazby při násilných a sexuálních trestních činech, zavést povinnou znalost němčiny před zahájením školní docházky, snížit daňovou zátěž nebo posílit policii. Naopak indiferentní či spíše negativní stanovisko zaujali obyvatelé Rakouska k úmyslu vlády podpořit větší flexibilitu vlády nebo zrušit zákaz kouření v gastronomii (Seidl 2017b).

\section{Závěr}

Rakouské parlamentní volby proběhnuvší v řijnu 2017 přinesly pět zásadních aspektů. Zaprvé, vládní spory vyvolané dlouhým vládnutím velké koalice a minimální personální obměnou zapríčinily zvýšenou poptávku elektorátu po ukončení období nečinnosti a provedení dlouho odkládaných reforem. Na uvedené skutečnosti nejlépe reagovali lidovci. Nástup Sebastiana Kurze do čela strany zdařile prezentovali ve smyslu něčeho nového a pozitivního. Umístněním několika osobností bez předchozích zkušeností s politikou na kandidátky spolu se změnou stranické barvy vytvořili u veřejnosti dojem otevřeného hnutí, které bude schopno posunout Rakousko dopředu.

Lidovci se rovněž dobře vypořádali s druhým podstatným aspektem parlamentních voleb - změnou tematických preferencí rakouského elektorátu zaprríčiněnou mezinárodní uprchlickou krizí. Azylovou a migrační agendu spolu s kriminalitou a vnitřní bezpečností pokládala rakouská veřejnost za důležitější než

\footnotetext{
${ }^{28} \mathrm{Na}$ základě spolkového zákona č. 344/1973 se lidové iniciativy (petice) mohou zúčastnit všichni občané disponující aktivním volebním právem. K tomu, aby byl návrh předložen $\mathrm{k}$ posouzení Národní radě, je potřeba získat 100000 podpisů. Následně je Národní rada povinna zabývat se požadavky Volksbegehren, avšak není vázána ke schválení návrhu.

${ }^{29}$ Svobodní původně požadovali stanovit hranici na úrovni 4 \% (256 000), lidovci 10 \% (640 000) občanů disponujících aktivním volebním právem.
} 
v minulosti dominující problematiku korupce, zvýšených nákladů na bydlení nebo reformy vzdělávací soustavy. Uvedené skutečnosti představovaly jeden z podstatných důvodů posílení lidovců a Svobodných, zatímco ostatní strany jen obtížně prosazovaly vlastní programatické priority. To by vysvětlovalo na rakouské poměry unikátní a dosud v odborné literatuře opomíjený růst voličské př́zně jak ÖVP, tak FPÖ, nebot' v rakouské historii v souvislosti s volbami do Národní rady až do roku 2017 vždy platilo, že posílení lidovců znamenalo oslabení Svobodných a naopak. Třetím aspektem je porážka úráadujícího spolkového kanclére, teprve třetí v rakouských dějinách. Christian Kern se nedokázal vymanit z tematické a strategické defenzivy způsobené rázným nástupem lidovců a teprve $\mathrm{v}$ posledních dvou týdnech volební kampaně dokázala SPÖ nalézt kombinaci témat pro úspěšnou mobilizaci svých př́ínivců a nevoličů.

Značný nárůst strategické volby sohledem na konstelaci vládní koalice představuje čtvrtý aspekt voleb do Národní rady. Preference rakouského voliče jsou stále méně určovány tradičními vazbami nebo skupinově vypěstovanými a determinovanými postoji. Důležitou roli hraje volební kampaň, neodmyslitelně spjatá s prostředky masové komunikace, a strategický záměr zabránit či napomoci určité koaliční formaci. Tato skutečnost odvrátila historicky nejhorší výsledek SPÖ, naopak u Zelených byla jednou z podstatných prríčin pozbytí parlamentní relevance.

Pátým aspektem je nové rozdělení koaličních variant při vyloučení možnosti menšinové vlády. Oba menší politické subjekty (NEOS, PILZ) nemohly na základě volebního výsledku plnit při povolebních vyjednáváních roli pomyslného „jazýčku na vahách“. Při neochotě socialistů a lidovců obnovit vládní spolupráci došlo v rakouské historii $\mathrm{k}$ nepř́lišs častému výraznému zvýšení koaličního potenciálu Svobodných.

Podle prognózy hospodářských expertů má současná vláda nadějné ekonomické předpoklady k prosazení nezbytných reforem (Stefan 2017). Jak lidovci, tak Svobodní slibovali nový styl vládnutí a mohou tedy od prosince 2017 dokázat, zda jsou schopni přejít od slov $\mathrm{k}$ činům a účinně řešit politické a společenské výzvy aktuální doby.

\section{Bibliografie}

Aichinger, Philipp (2017): „Als der ÖVP-Sieg schon feststand und doch noch die SPÖ gewann", Die Presse, 3. 8. 2017, online (https://diepresse.com/home/innenpolitik/ 5263328/Wahlkampflehren_Als-der-OeVPSieg-schon-feststand-und-doch-noch-die).

APA - Austria Press Agency (2017): „Grüne wollen enttäuschte SPÖ-Wähler für sich gewinnen“, Die Presse, 5. 10. 2017, online (https://diepresse.com/home/innenpolitik/ nationalratswahl/5297307/Gruene-wollen-enttaeuschte-SPOeWaehler-fuer-sichgewinnen).

APA - Austria Press Agency (2017): „ÖVP plakatiert jetzt den Parteinamen“, Der Standard, 28. 9. 2017, online (https://derstandard.at/2000064960358/OeVP-plakatiertjetzt-den-Parteinamen). 
APA - Austria Press Agency (2017): „Politologe Plasser. "Pilz könnte bei der Wahl die Grünen überholen", Die Kleine Zeitung, 27. 7. 2017, online (https://www.kleinezeitung.at/politik/politikaufmacher/5259051/Politologe-

Plasser_Pilz-koennte-bei-der-Wahl-die-Gruenen-ueberholen).

APA - Austria Press Agency (2017): „Schwarz-Blau in den Startlöchern“, Wiener Zeitung, 25. 10. 2017, online (https://www.wienerzeitung.at/nachrichten/oesterreich/politik/ 924979_Kurz-laedt-FPOe-zu-Koalitionsverhandlungen.html).

APA - Austria Press Agency (2017): „Wähler von ÖVP und FPÖ wünschen sich Schwarz-Blau“, Der Standard, 17. 10. 2017, online (http://derstandard.at/ 2000066199537/Waehler-von-OeVP-und-FPOe-wuenschen-sich-schwarz-blau).

Bauer, Gernot (2017): „SPÖ-Berater Silberstein organisierte rechte Facebook-Seite gegen Kurz", Profil, 30. 9. 2017, online (https://www.profil.at/oesterreich/wahrheit-kurzspoe-8342070).

Bayrhammer, Bernadette (2017): „Neos: Drei Standing Ovations für die Allianz mit Griss“, Die Presse, 8. 7. 2017, online (https://diepresse.com/home/innenpolitik/ 5248875/Neos_Drei-Standing-Ovations-fuer-die-Allianz-mit-Griss).

Bayrhammer, Bernadette (2017): „Neos: Mit neuem Namen auf zehn Prozent“, Die Presse, 7. 7. 2017, online (https://diepresse.com/home/innenpolitik/5247912/Neos_Mitneuem-Namen-auf-zehn-Prozent).

Bernard Martin A. (2014): „Team Stronach: Zeigen, wie es nicht geht. Eine Innenansicht von erratischer Politik samt (Misserfolgs-)Prognose." In: Andreas Khol, Sebastian Ofner, Stefan Karner a Dietmar Halper (eds.). Österreichisches Jabrbuch für Politik 35: 111-122.

BMI (2013): „Nationalratswahl 2013 - Wahltag, Stichtag, Gesamtergebnis“. Bundesministerium für Inneres, online (http://www.bmi.gv.at/412/Nationalratswahlen/ Nationalratswahl_2013/start.aspx\#pk_01).

BMI (2017): „Nationalratswahl 2017. Endgültiges Endergebnis“. Bundesministerium für Inneres, online (https://wahl17.bmi.gv.at/).

Brandstätter, Wolfgang (2014): „Was bedeutet „Neu regieren“ in der neuen Koalition aus meiner Sicht?" In: Andreas Khol, Sebastian Ofner, Stefan Karner a Dietmar Halper (eds.), Österreichisches Jahrbuch für Politik 35: 191-194.

Bundeskanzleramt (2017): „Regierungsprogramm 2017-2022. Zusammen für unser Österreich“, online (https://www.bundeskanzleramt.gv.at/documents/131008/569203/Regierungsprogramm_ 2017\%e2\%80\%932022.pdf/b2fe3f65-5a04-47b6-913d-2fe512ff4ce6).

Dachs, Herbert (2006): „Grünalternative Parteien“. In: Herbert Dachs et. al. Politik in Österreich. Das Handbuch. Wien: Manz Verlag: 389-401.

Die Grünen - Die Grüne Alternative (2017a): „Grüner Bundeskongress“, online (https://www.gruene.at/buko17).

Die Grünen - Die Grüne Alternative (2017b): Das ist grün. Wahlprogramm der Grünen Nationalratswahl 2017, Wien: Die Grünen - Die Grüne Alternative, Bundespartei.

Die Grünen - Die Grüne Alternative (2017c): „Die Grünen. Rudolfsheim-Fünfhaus. Schmelztiegel. Zeitschrift für eine ökologische und solidarische Alternative. Ausgabe 02/2017.“

Die Grünen - Die Grüne Alternative (2017d): Leták „Die Grünen. Am 15. Oktober: Ulrike Lunacek." 
Dimmel, Nikolaus a Alfred Noll (2017): „Woher? Wohin? Über den Einzug der „Liste Peter Pilz" in den Nationalrat." In: Thomas Hofer a Barbara Tóth (eds.), Wabl 2017. Loser, Leaks \& Leadership, Wien: Ärzte Verlag: 102-117.

Donig, Nikolaus (2017): „NEOS - Pinke Chancen Verwertung.“ In: Thomas Hofer a Barbara Tóth (eds.), Wabl 2017. Loser, Leaks \& Leadership, Wien: Ärzte Verlag: 90-101.

Ettinger, Karl (2017): „93,7 Prozent für die neue Grünen-Chefin Felipe.“ Die Presse, 25. 6. 2017, online (https://diepresse.com/home/innenpolitik/5240728/937-Prozent-fuerdie-neue-GruenenChefin-Felipe).

Fellner, Sebastian (2017): „Politologe Plasser: „Das war unglaublich schmerzhaft für Mitterlehner". Der Standard, 11. 5. 2017, online (http://derstandard.at/2000057331925/ Politologe-Plasser-Das-war-unglaublich-schmerzhaft-fuer-Mitterlehner).

Filzmaier, Peter (2009): „Ein Regierungsdesaster: Analyse der Nationalratswahl 2008،“ In: Andreas Khol, Sebastian Ofner, Stefan Karner a Dietmar Halper (eds.), Österreichisches Jabrbuch für Politik 30: 23-38.

Filzmaier, Peter (2014): „Das Team Stronach als Untoter.“ Die Kleine Zeitung, 18. 8. 2014, online (https://www.kleinezeitung.at/politik/innenpolitik/4181289/PolitAnalyse_DasTeam-Stronach-als-Untoter).

Föderl-Schmidt, Alexandra (2017): „Grüne Personalentscheidungen: Pragmatische Lösungen." Der Standard, 19. 5. 2017, online (http://derstandard.at/2000057999863/ Pragmatische-Loesungen).

FPÖ - Die Freiheitliche Partei Österreichs (2017c): „FPÖ Bildungsinstitut. Das freiheitliche Wirtschaftsprogramm“, online (https://www.fpoe.at/fileadmin/ user_upload/2017_freiheitliche_wirtschaftsprogramm_web.pdf).

FPÖ - Die Freiheitliche Partei Österreichs (2017d): „Das Bürgermagazin. Wir Wiener.“

FPÖ - Die Freiheitliche Partei Österreichs (2017e): „100 Forderungen: Norbert Hofer präsentiert FPÖ-Wahlprogramm“, online (https://www.fpoe.at/artikel/100forderungen-norbert-hofer-praesentiert-fpoe-wahlprogramm/).

FPÖ - Die Freiheitliche Partei Österreichs (2017f): „Österreicher verdienen Fairness. Freiheitliches Wahlprogramm zur Nationalratswahl 2017“, online (https://www.fpoe.at/fileadmin/user_upload/Wahlprogramm_8_9_low.pdf).

FPÖ - Die Freiheitliche Partei Österreichs (2017g): Leták „FPÖ. Die soziale Heimatpartei. Österreicher verdienen Fairness statt Stillstand, Streit und falscher Versprechen."

FPÖ - Die Freiheitliche Partei Österreichs (2017h): Leták „FPÖ. Die soziale Heimatpartei. HC Strache. Spitzenkandidat.“

FPÖ - Die Freiheitliche Partei Österreichs (2017i): Leták „FPÖ. Die soziale Heimatpartei. Norbert Hofer. Dritter Nationalratspräsident.“

FPÖ - Die Freiheitliche Partei Österreichs (2017a): „Auf HC Strache kann Österreich immer zählen.... während andere nur kurz vor Wahlen scheinbar klüger werden“, online (https://www.fpoe-parlamentsklub.at/artikel/auf-hc-strache-kann-oesterreichimmer-zaehlen/).

FPÖ - Die Freiheitliche Partei Österreichs (2017b): „Österreicher verdienen Fairness FPÖ startet Wahlkampagne“, online (https://www.fpoe.at/artikel/oesterreicherverdienen-fairness-fpoe-startet-wahlkampagne/).

Fritzl, Martin (2017): „Das Ende der Koalition.“ Die Presse, 12. 5. 2017 (Print-Ausgabe), online (https://diepresse.com/home/innenpolitik/5216312/Das-Ende-der-Koalition). 
Fritzl, Martin a Philipp Aichinger (2017): „Team Stronach tritt bei der Nationalratswahl nicht mehr an." Die Presse, 28. 6. 2017 (Print-Ausgabe), online (https://diepresse.com/home/innenpolitik/5242268/Team-Stronach-tritt-bei-der-

Nationalratswahl-nicht-mehr-an).

Gebhard, Josef (2017): „Häupl: Bei Rot-Blau droht Spaltung der SPÖ.“ Kurier, 17. 10. 2017, online (https://kurier.at/politik/inland/wahl/haeupl-bei-rot-blau-droht-spaltungder-spoe/292.594.931).

Gigler, Claudia (2017): „Steirisches Urgestein Werner Kogler übernimmt die Grünen.“ Die Kleine Zeitung, 18. 10. 2017, online (http://www.kleinezeitung.at/politik/ innenpolitik/5304433/Felipe-und-LunacekRuecktritt_Steirisches-Urgestein-WernerKogler.).

Hajek Peter, Andreas Kovar, Walter Osztovics a Alexandra Siegl (2008): „Die österreichische Nationalratswabl 2008 und die standortpolitischen Folgen. Politische Analyse und Empfehlungen für Unternehmen." Kovar \& Köppl. Public Affairs Consulting, Peter Hajek. Public Opinion Strategies, online (https://www.publicaffairs.cc/wpcontent/uploads/2016/10/ WahlanalyseNationalratswahl2008-1.pdf).

Hloušek, Vít (2008): „Konfliket versus konsenzus. Konfliktni linie, stranické systémy a politické strany v Rakousku 1860-2006“. Brno: Mezinárodní politologický ústav Masarykovy univerzity.

Hnát, Jakub (2013): „Rakouské parlamentní volby 2013“. In: Evropská volební studia 8, č. 2, s. 166-176.

Höbelt, Lothar (2014): „Wohldosierte Langweile: der Wahlkampf der FPÖ.“ In: Thomas Hofer a Barbara Tóth (eds.): Wabl 2013. Macht-Medien-Milliardäre. Wien: Lit Verlag: 61-68.

Hofer, Thomas (2014): „Von Mäusern und Milliardären.“ In: Thomas Hofer a Barbara Tóth (eds.): Wabl 2013. Macht-Medien - Milliardäre. Wien: Lit Verlag: 5-36.

Hofer, Thomas a Barbara Tóth (2007): Kanzler, Kampagnen, Kapriolen. Analysen zur Nationalratswahl, Wien - Berlin: LIT Verlag.

Hofer, Thomas a Barbara Tóth (2017): Wabl 2017. Loser, Leaks \& Leadership, Wien: Ärzte Verlag

Hofer, Thomas a Barbara Tóth (2008): Wabl 2008. Strategien - Sieger - Sensation, Wien: Molden Verlag.

Jenny Marcelo a Wolfgang C. Müller (2014): „Das Wahlergebnis.“ In: Sylvia Kritzinger, Wolfgang C. Müller a Klaus Schönbach (eds.), Die Nationalratswabl 2013. Wie Parteien, Medien und Wählerschaft zusammenwirken. Wien-Köln-Weimar: Böhlau Verlag: 215-230.

Joachim Riedl a Florian Gasser (2017): „Österreich: Österreichische Grünen-Chefin vor Rücktritt." Die Zeit, 17. 5. 2017, online (http://www.zeit.de/politik/ausland/201705/oesterreich-eva-glawischnig-gruene).

John, Gerald (2017): „,Grüne Spitzenkandidatin Lunacek will Pilz halten - dieser schlägt Angebot aus." Der Standard, 26. 6. 2017, online (http://derstandard.at/ 2000059805695/Letztes-Angebot-Gruene-Spitzenkandidatin-Lunacek-will-Pilz-halten).

John, Gerald (2017): „ÖVP-FPÖ-Pläne: Härtere Strafen, weniger Steuern, Sozialkürzung für Zuwanderer." Der Standard, 3. 11. 2017, online (https://derstandard.at/ 2000067097140/Koalitionsverhandler-sind-ein-gutes-Stueck-vorwaerts-gekommen). 
Jungwirth, Michael (2017): „Kurz setzt auf sein Kernteam.“ Die Presse, 24. 6. 2017 (PrintAusgabe), online (https://diepresse.com/home/innenpolitik/5240138/Kurz-setzt-aufsein-Kernteam?from=suche.intern.portal).

Kaltenbrunner, Stefan (2017): „Anwalt Noll: "ORF betätigt sich als Staatsfunk". Kurier, 4. 10. 2017, online (https://kurier.at/politik/inland/wahl/anwalt-noll-orf-betaetigt-sichals-staatsfunk/289.598.533).

Khol, Andreas (2014): „MIGROKO vor dem Ende. Auf dem Weg in eine neue Republik." In: Andreas Khol, Sebastian Ofner, Stefan Karner a Dietmar Halper (eds.), Österreichisches Jabrbuch für Politik 35: 3-14.

Kittner, Daniela (2017): „Unabhängige" Irmgard Griss kandidiert für Neos-Liste.“ Kurier, 1. 7. 2017, online (https://kurier.at/politik/inland/unabhaengige-irmgard-grisskandidiert-fuer-neos-liste/272.667.791).

Kittner, Daniela (2017): „Zulasten der FPÖ: Kurz zieht ÖVP auf ersten Platz.“ Kurier 21. 5. 2017, online (https://kurier.at/politik/inland/zulasten-der-fpoe-kurz-zieht-oevp-aufersten-platz/265.095.487).

Kopeinig, Margaretha (2017): Bachmayer: "Kern ist nun eine lahme Ente". Kurier, 2. 10. 2017, online (https://kurier.at/politik/inland/kern-ist-nun-eine-lahme-ente/289.415.680). Kriechbaumer, Robert (2016): „Es reicht!": Die Regierung Gusenbauer - Molterer. Österreich 2007/2008, Wien - Köln - Weimar: Böhlau Verlag.

Kritzinger, Sylvia, Wolfgang C. Müller a Klaus Schönbach (2014): „Lektionen, Konsequenzen, Ausblicke.“ In: Sylvia Kritzinger, Wolfgang C. Müller a Klaus Schönbach (eds.), Die Nationalratswabl 2013. Wie Parteien, Medien und Wäblerschaft zusammenwirken. Wien, Köln, Weimar: Böhlau Verlag: 231-240.

Kurz, Sebastian (2014): „Neu regieren.“ In: Andreas Khol, Sebastian Ofner, Stefan Karner a Dietmar Halper (eds.), Österreichisches Jahrbuch für Politik 35: 195-198.

Lindorfer, Raffaela (2017): „Türkis-blaue Liaison laut Umfrage klarer Favorit der Österreicher.“, online (https://kurier.at/politik/inland/tuerkis-blaue-liaison-lautumfrage-klarer-favorit-der-oesterreicher/277.877.277).

Lindorfer, Raffaela a Bernhard Gaul (2017): „Lunacek warnt: "Wer SPÖ wählt, kann mit rot-blau aufwachen". Kurier, 26. 9. 2017, online (https://kurier.at/politik/inland/wahl/ lunacek-warnt-wer-spoe-waehlt-kann-mit-rot-blau-aufwachen/288.484.278).

Lindorfer, Raffaela a Johann Hager (2017): „KURIER-OGM-Umfrage: Kurz führt, Kern und Strache gleichauf.“ Kurier, 23. 7. 2017, online (https://kurier.at/politik/inland/ kurier-ogm-umfrage-kurz-fuehrt-kern-und-strache-gleichauf/276.515.353).

Lopatka, Reinhold (2014): „Neu regieren, neu integrieren, neu diskutieren.“ In: Andreas Khol, Sebastian Ofner, Stefan Karner a Dietmar Halper (eds.), Österreichisches Jabrbuch für Politik 35: 199-206.

Luther, Kurt, Richard (2005): „Die Freiheitliche Partei Österreichs (FPÖ) und das Bündnis Zukunft Österreich (BZÖ).“ Keele European Parties Research Unit. Working Paper 22, online (https://www.keele.ac.uk/media/keeleuniversity/group/kepru/KEPRU\%20WP\%2022.pdf).

Luther, Kurt, Richard (2006): „Die Freiheitliche Partei Österreichs (FPÖ) und das Bündnis Zukunft Österreich (BZÖ).“ In: Herbert Dachs et. al. Politik in Österreich. Das Handbuch. Wien: Manz Verlag: 364-388.

Maderthaner, Philipp (2017): „Der Wahlkampf der Superlative.“ In: Thomas Hofer a Barbara Tóth (eds.), Wabl 2017. Loser, Leaks \& Leadership, Wien: Ärzte Verlag: 50-61. 
Marchart, Jan Michael (2015): „Team Stronach, ein Auslaufmodell.“ Wiener Zeitung, 14. 12. 2015, online (https://www.wienerzeitung.at/nachrichten/oesterreich/politik/791103_TeamStronach-ein-Auslaufmodell.html).

Marquart, Franziska (2013): „Rechtspopulismus im Wandel. Wahlplakate der FPÖ von 1978-2008.“ Österreichische Zeitschrift für Politikwissenschaft 42(4): 358-371.

Mayer, Thomas (2017): „Kanzler in Brüssel: Ein Kurztrip, der die Sorgen um Österreich zerstreute.“ Der Standard, 20. 12. 2017, online (http://derstandard.at/2000070780833/ Kanzler-in-Bruessel-Ein-Kurztrip-der-Sorgen-um-Oesterreich-zerstreute?ref=rec).

Mayer, Thomas (2017): „Kurz in Brüssel: Juncker sieht Österreich als verlässlich an.“ Der Standard, 20. 12. 2017, online (https://derstandard.at/2000070717697/Kurz-inBruessel-Juncker-haelt-Kanzler-fuer-verlaesslichen-Partner).

Mayr, Peter, Nina Weißensteiner, Markus Rohrhofer a Jutta Berger (2017): „Die Mission gescheitert: Felipe und Lunacek gehen, Kogler kommt.“ Der Standard, 18. 10. 2017, online (http:/ /derstandard.at/2000066211780/Mission-gescheitert-Felipe-und-Lunacek-gehenKogler-kommt).

Metzer, Ida (2017): „Rot, Grün, Neos kann ich mir vorstellen." Kurier, 21. 5. 2017, online (https://kurier.at/politik/inland/rot-gruen-neos-kann-ich-mir-vorstellen/265.097.678).

Metzger, Ida a Raffaela Lindorfer, (2016): „Das Team Stronach - klinisch tot“. Kurier, 25. 7. 2016, online (https://kurier.at/politik/inland/das-team-stronach-klinisch-tot/ 211.854.804).

Mittelstaedt, Katharina, Nina Weissensteiner a Oswald Günther (2017): „ÖVP und FPÖ verkünden erste Einigungen im Sicherheits- und Asylbereich.“ Der Standard, 17. 11. 2017, online (https://derstandard.at/2000068019145/OeVP-und-FPOe-verkuendenerste-Einigungen-im-Sicherheitsbereich).

Müller, Walter (2017): „ÖVP-Klubklausur: Mitterlehners Suche nach einem „Plan B“. Der Standard, 12. 1. 2017, online (https://derstandard.at/2000050657256/OeVPKlubklausur-Mitterlehners-Suche-nach-einem-Plan-B).

Müller, Wolfgang C. (2006): „Die Österreichische Volkspartei.“ In: Herbert Dachs et. al. (eds.): Politike in Österreich. Das Handbuch. Wien: Manz Verlag, 2006: 341-363.

Neisser, Heinrich (2014): „Regierungsprogramm 2013-2018.“ In: Andreas Khol, Sebastian Ofner, Stefan Karner a Dietmar Halper (eds.), Österreichisches Jabrbuch für Politik 35: $123-132$.

NEOS - Das Neue Österreich und Liberales Forum (2017a): „NEOS. Vorwahlen. Nationalratswahl 2017“, online (https://ichtuwas.neos.eu/vorwahlen2017/ informieren).

NEOS - Das Neue Österreich und Liberales Forum (2017b): Leták „NEOS. Das Zukunftsmanifest für ein neues Österreich.“

NEOS - Das Neue Österreich und Liberales Forum (2017c): Leták „Die Allianz für Freiheit und Verantwortung. NEOS am 15. 10.“

NEOS - Das Neue Österreich und Liberales Forum (2017d): Leták „NEOS. Nicht rechts, nicht links, nach vorne.“

Neuwirth, Dietmar (2017): „Kern: "Bereiten uns auf Opposition vor". Die Presse, 22. 10. 2017, online (http://diepresse.com/home/innenpolitik/5307616/Kern_Bereiten-unsauf-Opposition-vor?direct $=5307616 \& \_v l \_b a c k l i n k=/$ home $/$ innenpolitik / index.do\&selChannel $=6567$ ). 
Neuwirth, Dietmar (2017): Schützenhöfer: „Alle werden sich bemühen, dass Kurz übernimmt." Die Presse, 10. 5. 2017, online (https://diepresse.com/home/innenpolitik/ 5215508/Schuetzenhoefer_Alle-werden-sich-bemuehen-dass-Kurz-uebernimmt).

Noll, Aflred (2017): „Politisch obsolet: Grüne auf Selbstzerstörungstrip.“ Der Standard, 26. 6. 2017, online (https://derstandard.at/2000059831163/Politisch-obsolet-Grueneauf-Selbstzerstoerungstrip).

Nowak, Rainer a Martin Stuhlpfarrer (2017): „Kulissengespräche. Irmgard Griss doch nicht auf der Liste Kurz.“ Die Presse, 9. 6. 2017, online (https://diepresse.com/ home/meinung/marginalien/5232581/Kulissengespraeche_Irmgard-Griss-doch-nichtauf-der-Liste-Kurz).

Oswald Günther et. al. (2017): „Silbersteins Dirty Campaigning: Was wir bisher wissen und was nicht.“ Der Standard, 2. 10. 2017, online (https://derstandard.at/ 2000065174492/Silbersteins-Dirty-Campaigning-Was-wir-bisher-wissen-und-was-nicht). ÖVP - Die Österreichische Volkspartei (2017a): „Das Programm der Liste Sebastian Kurz - die neue Volkspartei zur Nationalratswahl 2017. Der neue Weg. Teil 1: Neue Gerechtigkeit \& Verantwortung“, online (https://diepresse.com/mediadb/pdf/ Neue\%20Gerechtigkeit.pdf).

ÖVP - Die Österreichische Volkspartei (2017b): „Das Programm der Liste Sebastian Kurz - die neue Volkspartei zur Nationalratswahl 2017. Der neue Weg. Teil 2: Aufbruch \& Wohlstand“, online (http://diepresse.com/mediadb/ Wahlprogramm_Teil2_Aufbruch\%20und $\% 20$ Wohlstand.pdf)

ÖVP - Die Österreichische Volkspartei (2017c): „Das Programm der Liste Sebastian Kurz die neue Volkspartei zur Nationalratswahl 2017. Der neue Weg. Teil 3: Ordnung \& Sicherheit", online (https://www.sebastian-kurz.at/cache/images/assets.contentful.com/ i520qwheh9j7/2xLFiGx0vOkSkoSU4uQq8y/17d2ac866958896a8ee2e38ed1c7dcca/72_S K_Programm_Teil3_Einzelseiten_WEB.pdf).

ÖVP - Die Österreichische Volkspartei (2017d): Leták „Kurz 2017. Ein neuer Stil. Es ist Zeit.“

ÖVP - Die Österreichische Volkspartei (2017e): Leták „Kurz 2017. Kurz gesagt. Im TVDuell gegen HC Strache."

ÖVP - Die Österreichische Volkspartei (2017f): Leták. „Kurz 2017. Kurz gesagt. In der Elefantenrunde.“

Pechar, Brigitte (2017): „Große Einigkeit - vor allem gegen die FPÖ.“ Die Wiener Zeitung, 26. 9. 2017, online (https://www.wienerzeitung.at/nachrichten/oesterreich/politik/ 919420_Grosse-Einigkeit-vor-allem-gegen-die-FPOe.html).

PILZ - Liste Peter Pilz (2017a): „Satzung der politischen Partei „LISTE PETER PILZ“, online (https://listepilz.at/wp-content/uploads/2017/09/Statuten_LPP.pdf).

PILZ - Liste Peter Pilz (2017b): Leták „Liste Pilz. Für unsere Heimat Österreich. Unsere Kandidatinnen und Kandidaten.“

PILZ - Liste Peter Pilz (2017c): Leták „Viele regieren, einer kontrolliert. Peter Pilz.“

PILZ - Liste Peter Pilz (2017d): profil Petera Pilze, online (https://listepilz.at/peter-pilz/).

Pink, Oliver (2017): „Die Ära Faymann. Wer war Werner Faymann? Und was bleibt von seiner Kanzlerschaft?" In: Andreas Khol, Sebastian Ofner a Stefan Karner (eds.), Österreichisches Jabrbuch für Politik 38: 231-236.

Plasser Fritz a Franz Sommer (2018): Wahlen im Schatten der Flüchtlingskrise. Parteien, Wähler und Koalitionen im Umbruch, Wien: Facultas. 
Plescia, Carolina a Julian Aichholzer (2018): „Zum Schicksal der Grünen bei der österreichischen Nationalratswabl 2017: hausgemachtes Debakel?", online (http://viecer.univie.ac.at/blog/ detail/news / zum-schicksal-der-gruenen-bei-der-oesterreichischen-nationalratswahl2017-hausgemachtes-debakel/).

Pöttler, Stefan (2009): Eine unmögliche Koalition. In: Thomas Hofer a Barbara Tóth (eds.): Wahl 2008. Strategien - Sieger - Sensation, Wien: Molden Verlag: 146-159.

Prapotnik, Katrin (2015): „Die Policy-Bilanz der Regierung Faymann I. Eine Studie zur Anwendbarkeit der Mandatstheorie." Österreichische Zeitschrift für Politikwissenschaft 44 (2): 1-14. Prior, Thomas (2017): „Liste Pilz“: Feldversuch mit Einzelkämpfern.“ Die Presse, 26. 7. 2017 (Print-Ausgabe), online (https://diepresse.com/home/innenpolitik/5258309/ Liste-Pilz_Feldversuch-mit-Einzelkaempfern).

Prior, Thomas (2017): „Schwarz-Blau im Endspurt.“ Die Presse, 27. 11. 2017, online (https:/ / diepresse.com/home/innenpolitik/5328363/SchwarzBlau-im-Endspurt).

Redaktion (2017): „Burgenlands ÖVP-Chef für „neue Politik“ mit Kurz.“ Die Presse, 11. 5. 2017 (Print-Ausgabe), online https://diepresse.com/home/innenpolitik/5215634/ Burgenlands-OeVPChef-fuer-neue-Politik-mit-Kurz).

Redaktion (2017): „Ein Monat Verhandlungen: Was bisher herauskam.“ Kurier, 27. 11. 2017, online (https://kurier.at/politik/inland/nach-einem-monat-koalitionsverhandlungen-diebisherigen-ergebnisse/299.811.137).

Redaktion (2017): „Grünen-Chefin Glawischnig soll vor Rücktritt stehen.“ Der Standard, 18. 5. 2017, online (http://derstandard.at/2000057821946/Spekulationen-ueberRueckzug-von-Gruenen-Chefin-Glawischnig).

Redaktion (2017): „Heinz-Christian Strache: "Ich bin gelassener und ruhiger geworden". Der Kurier, 1. 10. 2017, online (https://kurier.at/politik/inland/wahl/fpoe-chef-heinzchristian-strache-ich-bin-gelassener-und-ruhiger-geworden/289.233.820).

Redaktion (2017): „Kurz nimmt Anleihe bei Kreisky.“ Tiroler Tageszeitung 24. 6. 2017 (Print-Ausgabe), online (http://www.tt.com/politik/innenpolitik/13134562-91/kurznimmt-anleihe-bei-kreisky.csp).

Redaktion (2017): „Profil Umfrage: Liste Kurz/VP liegt derzeit deutlich vor SPÖ.“ Profil, 20. 5. 2017, online (https://www.profil.at/oesterreich/umfrage-liste-kurz-vp-spoe8154322).

Riedl Joachim a Florian Gasser (2017): „Österreich: Österreichische Grünen-Chefin vor Rücktritt.“ Die Zeit, 17. 5. 2017, online (http://www.zeit.de/politik/ausland/201705/oesterreich-eva-glawischnig-gruene).

Sartori, Giovanni (2005): Strany a stranické systémy. Schéma pro analýzu. Brno: Centrum pro studium demokracie a kultury.

Seidl, Conrad (2017): „Kanzlerduell Kurz gegen Kern schmälert FPÖ-Chancen auf Wahlsieg." Der Standard, 26. 5. 2017, online (http://derstandard.at/2000058258028/ Kanzlerduell-Kurz-gegen-Kern-schmaelert-FPOe-Chancen-auf-Wahlsieg).

Seild, Conrad (2017): „Umfrage zeigt breite Zustimmung zum Regierungsprogramm.“ Der Standard, 27. 12. 2017, online (https://derstandard.at/2000071039515/UmfrageBreite-Zustimmung-zum-Grossteil-des-Regierungsprogramms).

Schieder, Andreas (2014): „Politik auf Dialog ausrichten.“ In: Andreas Khol, Sebastian Ofner, Stefan Karner a Dietmar Halper (eds.), Österreichisches Jabrbuch für Politik 35: 211-215. 
Sittinger, Ernst, Michael Jungwirth a Claudia Gigler, (2017): „Glawischnig gibt um zehn Uhr persönliche Erklärung ab." Die Kleine Zeitung, 18. 5. 2017, online (https://www.kleinezeitung.at/politik/innenpolitik/5219842/Glawischnig-vor-

Ruecktritt_Glawischnig-gibt-um-zehn-Uhr).

SORA/ISA. Institut für Strategieanalysen (2008): Nationalratswahl 2008, online (http://www.sora.at/fileadmin/downloads/wahlen/2008_nrw_wahlanalyse.pdf.

SORA/ISA. Institut für Strategieanalysen (2013): Wahlanalyse Nationalrat 2013, online (http://www.sora.at/fileadmin/downloads/wahlen/2013_NRW_Wahlanalyse.pdf).

SORA/ISA. Institut für Strategieanalysen (2017): Wahlanalyse Nationalrat 2017, online (http://www.sora.at/fileadmin/downloads/wahlen/2017_NRW_Wahlanalyse.pdf).

SPÖ - Die Sozialdemokratische Partei Österreichs (2017a): Plan A für Austria. Programm für Wohlstand, Sicherheit \& gute Laune. Wien: Sozialdemokratische Partei Österreichs., dostupné rovněž online (https://spoe.at/Plan-A-2017.pdf).

SPÖ - Die Sozialdemokratische Partei Österreichs (2017b): „Koalitionsbedingungen zur

Nationalratswahl 2017. Damit der Aufschwung bei allen ankommt.“, online (https://spoe.at/sites/default/files/koalitionsbedingungen.pdf).

SPÖ - Die Sozialdemokratische Partei Österreichs (2017b): Leták „Bundeskanzler Christian Kern. Damit sie bekommen, was Ihnen zusteht.“

SPÖ - Die Sozialdemokratische Partei Österreichs (2017d): „SPÖ präsentiert Plakate für NR-Wahl: „Holen Sie sich, was Ihnen zusteht!“, online (https://spoe.at/story/spoepraesentiert-plakate-fuer-nr-wahl- $\% \mathrm{E} 2 \% 80 \% 9$ Eholen-sie-sich-was-ihnenzusteht $\% \mathrm{E} 2 \% 80 \% 9 \mathrm{C})$.

SPÖ - Die Sozialdemokratische Partei Österreichs (2017e): „Neue Plakatserie der SPÖ: Veränderung mit Verantwortung", online (https://spoe.at/story/neue-plakatserie-derspoe-veraenderung-mit-verantwortung).

SPÖ - Die Sozialdemokratische Partei Österreichs (2017f): Leták „Bundeskanzler Christian Kern. Veränderung mit Veranwortung. Erfahrung. Am 15. 10. 2017 Liste 1 SPÖ.“

SPÖ - Die Sozialdemokratische Partei Österreichs (2017g): „Es geht ums Ganze!“ - Der Erfolg Österreichs muss bei allen Menschen ankommen“, online (https://spoe.at/story/\%E2\%80\%9Ees-geht-ums-ganze $\%$ E2\%80\%9C-\%E2\%80\%93der-erfolg-oesterreichs-muss-bei-allen-menschen-ankommen).

SPÖ - Die Sozialdemokratische Partei Österreichs (2017h): Leták „Veränderung mit Verantwortung. Bundeskanzler Christian Kern. ORF-Konfrontation Kern vs. Kurz. Kern klarer Sieger im TV-Duell.“

SPÖ - Die Sozialdemokratische Partei Österreichs (2017i): Leták „Veränderung mit Verantwortung. Bundeskanzler Christian Kern. ORF-Elefantenrunde. Kern. Damit alle vom Erfolg profitieren.“

Stefan, Leopold (2017): „Wifo: Österreichs Budget saniert sich bis 2019 von selbst.“ Der Standard, 24. Oktober 2017, online (https://derstandard.at/2000066575387/WifoOesterreich-hat-weiterhin-gute-Wachstumsaussichten).

Steiner-Gashi, Ingrid (2017): „Juncker lobt Kurz - und kritisiert Kneissl.“ Kurier, 19. 12. 2017, online (https://kurier.at/politik/inland/kurze-charmeoffensive-in-bruesseljuncker-lobt-kurz-und-kritisiert-kneissl/302.877.266).

Strobl, Karin (2017): „Der Grüne Abstrurz - Der Versuch einer Rekapitulation.“ In:

Thomas Hofer a Barbara Tóth (eds.), Wabl 2017. Loser, Leaks \& Leadership, Wien: Ärzte

Verlag: 118-129. 
Šepták, Miroslav (2008): „Co prínesly rakouské parlamentní volby? Mezinárodní politika 32(11): 21-23.

Šepták, Miroslav (2017): „Zelení mají novou předsedkyni a touží po vládě.“ Demokraticky stred, 21. 5. 2017, online (http://www.demokratickystred.cz/zeleni-maji-novoupredsedkyni-touzi-po-vlade/).

Temel, Peter (2017): „Worum geht es eigentlich im Grünen-Streit?“ Kurier, 3. 4. 2017, online (https://kurier.at/politik/inland/streit-zwischen-glawischnig-und-jungen-gruenenworum-geht-es-eigentlich/256.037.939).

Thalhammer, Anna (2017): „Tal Silberstein und die Wahrheit über die SchmutzkübelKampagnen der SPÖ.“ Die Presse, 30. 9. 2017, online (https://diepresse.com/home/innenpolitik/nationalratswahl/5294429/Tal-Silbersteinund-die-Wahrheit-ueber-die-SchmutzkuebelKampagnen).

Tóth, Barbara (2017): „Der Silberstein-Skandal.“ In: Thomas Hofer a Barbara Tóth (eds.), Wabl 2017. Loser, Leaks \& Leadership, Wien: Ärzte Verlag, 130-151.

Uhl, Hannes (2017): „Ein Wahlkamopf im Krisenmodus. Ein monothematischer Wahlkampf, eine Causa prima und viel Gegenwind. Eine Kampagne gegen alle Widerstände." In: Thomas Hofer a Barbara Tóth (eds.), Wabl 2017. Loser, Leaks \& Leadership, Wien: Ärzte Verlag: 62-75.

Ulram Peter A. a Franz Sommer (2016): „Analyse der Landtagswahlen 2015: Burgenland, Steiermark, Oberösterreich, Wien. Gebremste und umgebremste Abstrürze, bunte Regierungskonstellationen nach Regionalwahlen." In: Andreas Khol, Sebastian Ofner a Stefan Karner (eds.), Österreichisches Jabrbuch für Politik 37: 3-23.

Ulram Peter A. a Franz Sommer (2017): „Bundespräsidentenwahlen 2016: Politische Einstellungen und Motive der Wähler, regionale Trends und Wählerströme. Erster Wahlgang 24. 4., Stichwahl 22. 5., Wiederholung der Stichwahl 4. 12." In: Andreas Khol, Sebastian Ofner a Stefan Karner (eds.), Österreichisches Jahrbuch für Politike 38: 3-36.

Ulram, Peter A. (2009): „Ein verspielter Sieg und eine siegreiche Zeitungspartei - Analyse der Nationalrarswahl 2008." In: Andreas Khol, Sebastian Ofner, Stefan Karner a Dietmar Halper (eds.), Österreichisches Jabrbuch für Politik 30: 5-22.

Ultsch, Christian, Thomas Prior a Rainer Nowak (2017): Flucht. Wie der Staat die Kontrolle verlor. Wien: Molden 